

\section{Editorial Structure}

\section{Editorial Board}

Acceptance of papers is undertaken by the team of Associate Editors under the guidance of the Editor-in-Chief. All papers are refereed. Editorial Board members adjudicate in the case of conflicting or adverse reports.

\section{Meet the Editorial Board}

\section{Editors-in-Chief}

- George Koutsantonis, University of Western Australia

- John D. Wade, University of Melbourne and Florey Institute of Neuroscience and Mental Health

\section{Associate Editors}

- Manabu Abe, Hiroshima University

- Stuart Batten, Monash University

- Paul Bernhardt, University of Queensland

- Cinzia Chiappe, University of Pisa

- Martyn Coles, Victoria University of Wellington

- Charlotte Conn, School of Applied Science, RMIT

- Deanna M. D'Alessandro, University of Sydney

- Peter Duggan, CSIRO

- Amanda Ellis, University of Melbourne

- Richard Hoogenboom, Ghent University

- T. S. Andy Hor, The University of Hong Kong

- Craig Hutton, University of Melbourne

- Amir Karton, University of Western Australia

- Anastasios (Tash) Polyzos, CSIRO CMHT

- Jenny Pringle, Deakin University

- Greg Qiao, University of Melbourne

- Devon Shipp, Clarkson University

- Pall Thordarson, University of New South Wales

- Xinhua Wan, Peking University

- Jonathan White, University of Melbourne

Publisher

\section{- Jenny Foster}




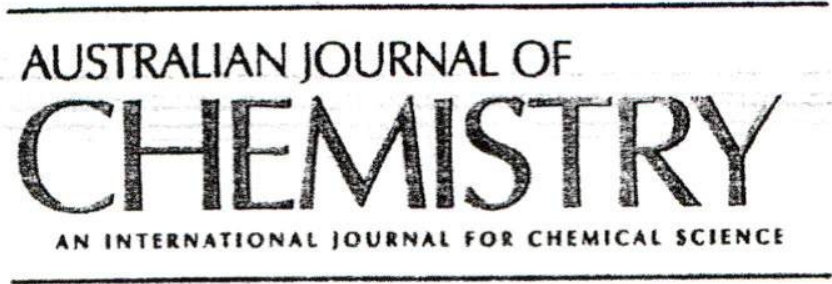

Volume $64 \quad$ Number $4 \quad 2011$

\section{CONTENTS}

Special issue: A dedication to Professor Atheistan L. J. Beckwtth

Guest editor: Peter J. Duggan

\section{Foreword}

Foreword to Professor Athelstan L. J. Beckwith Special Issue

$$
\text { P.J. Duggan } 355
$$

\section{Reviews}

Atheistan L. J. Beckwith and the Flowering of Hex-5-enyl Radical Cyclization Chemistry.

The Adelaide Years A. K. Serelis 358

Cyclohexane-1,3-dione Oxime Ether Grass-Specific Herbicides and the Discovery of Butroxydim X. G. Hatson 367

Profluorescent Nitroxides as Sensitive Probes of Oxidative Change and Free Radical Reactions J. P. Blinco, K. E. Fairfull-Smith, B. J. Morrow, S. E. Bottle 373

Full Papers

Destabilization of Conjugated Systems of $\alpha$-Dicarbonyls and of Cyanogen A. A. Zavilsas, D. W. Rogers. N. Molsunaga $\quad 390$

O-H Bond Dissociation Energies B. Chan, M. Morris, L. Radom 394

The Distal Effect of $N$-Electron-withdrawing Groups on the Stability of Peptide Carbon Radicals J. Ho, M. L. Coote, C. I. Easior 493

Synthetic and Computational Studies of Acyl Radical Cyclizations with B-Alkoxyacrylates: Formal Synthesis of $( \pm$ )-Longianone H. M. Aitken, C. H. Schiesser. C. D. Donner 409

Fluoroazaindolines by an Uncommon Radical ipso-Substitution of a C-F Bond Y. Laot, L. Petit, N. D. M. Tran, S. Z Zard 416

A Profluorescent Azaphenalene Nitroxide for Nitroxide-Mediated Polymerization J. M. Colwell, J. P. Blinco, C. Hulbert, K. E. Fairfull-Smith, S. E. Bottle 426

A Potential New RAFT-Click Reaction or a Cautionary Note on the Usc of Diazomethane to Methylate RAFT-synthesized Polymers M. Chen, G. Moad, E. Rizzardo 433

An Oxidized Abasic Lesion as an Intramolecular Source of DNA Adducts L. Guan, M. M. Greenberg 438

Reaction of $N$-Acyloxy- $N$-alkoxyamides with Biological Thiol Groups S. A. Giover. M. Adams 443

Synthesis of 2,3-Dihydro-4(1H)-quinolones and the Corresponding $4(1 H)$-Quinolones via Low-Temperature Fries Rearrangement of $N$-Arylazetidin-2-ones

J. Lange, A. C. Bissember. M. G. Banwell, 1. A. Cade 454

Stuaies Directeci Towads the Preparation of Prubes for the Phwtoaffinity Labelling of Gibberellin Receptors J. R. Crow, P. M. Chandler. L. N. Mander 471

Phytochemical Study of Fagraea spp. Uncovers a New Terpene Alkaloid with Anti-Inflammatory Properties Suciati, L. K. Lambert, B. P. Ross, M. A. Deseo. M. J. Garson 489

Wood Protection Properties of Quaternary Ammonium Spiroborate Esters Derived rrom Alkyl Tartrates J. M. Carr, P. J. Duggan, D. G. Humphrey, J. A. Platts, E. M. Tyndall 495 


\section{Bukti online}

http://www publish csiro.au/paper/CH10421.htm 


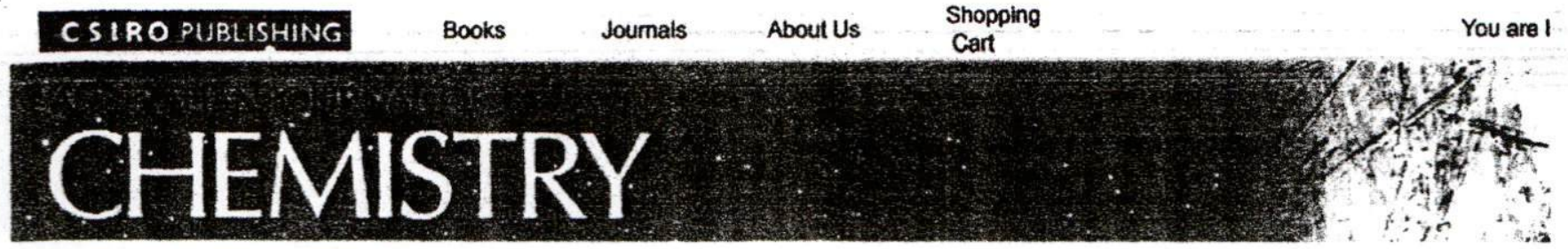

An intemational joumal for chemical science

\section{Search}

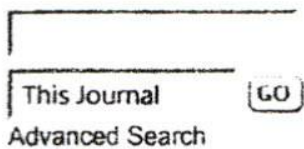

Advanced Search

\section{- Journal Home About the Joumal New Editor-in-Chief Editorial Structure Contacts For Advertisers \\ - Content \\ Online Earty \\ Current Issue Just Accepted All issues \\ Virtual issues Special iesues Research Fronts Sample issue Covers \\ - For Authors General Information Scope \\ Submit Articie Author instructions Open Access \\ - For Referees Referee Guidelines Review an Auticle \\ - For Subscribers Subscription Prices Customer Service Print Pubilication Uates \\ E-Alerts}

Subscribe to our Email Alert or $\mathrm{Ei}$ feeds for the latest joumal papers.

Connect with us

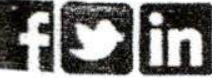

Affiliated with $\mathrm{RACl}$

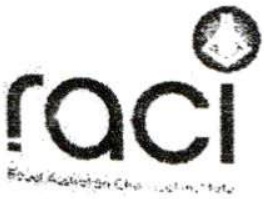

Royal Australian Chemical Institute
Table of Contents

《< Prevlous lssue | Next lssue $>$

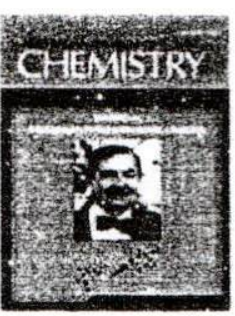

\section{Australian Journal of Chemistry}

Volume 64 Number 42011

A Dedication to Professor Athelstan L. J. Beckwith
Table of Contents

PDF $(80 \mathrm{~KB})$

Foreword to Professor Athelstan L. J. Beckwith Special Issue

Peter J. Duggan

pp. $355-357$

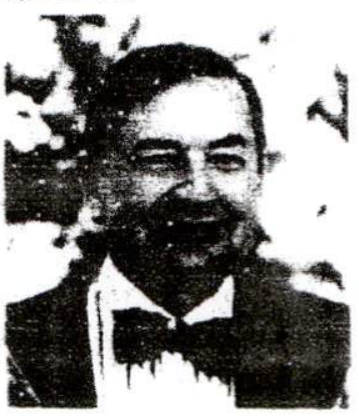

Professor Atheistan Beckwith, FRACI, FAA, FRS, OA passed away on 15th May 2010. He was a giant of Australian Chemistry and his contributions to the field of physical organic chemistry and free radical research have had major impacts worldwide. Athel published over 200 papers which have received more than 9900 citations. He was a great supporter of the Australian Joumal of Chemistry, publishing more articles in our journal than anywhere eise. This Special Issue of the Australian Joumal of Chemistry is dedicated to him.

Full Text | PDF $(235 \mathrm{~KB})$

Athelstan L. J. Beckwith and the Flowering of Hex-5-enyl Radical Cyclization Chemistry. The Adelaide Years

Algirdas K. Sereils

pp. 358-366

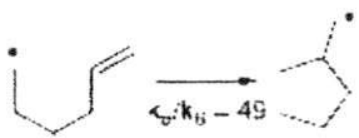

The late Professcr Athel Beckwith made many significant contributions to the emergence of free radicais as controllable and selective reactive intermediates in synthesis. This account revisits his earty mechanistic studies on the cyclization of hex-5-nyl radical systems, considered to be his most important work and the springboard for a multitude of applications in the synthesis of polycyclic natural products and related compounds. 
Studies Directed Towards the Preparation of Probes for the Photcaffinity Labelling of Gibberellin Receptors

James R. Crow, Peter M. Chandier and Lewis N. Mander

pp. 471-488

(C)

(1)

Model studies for the preparation of photoaffinity probes designed to explore the nature of gibbereilin receptor sites have provided a wide range of gibberellin derivatives that should afford useful scaffolds for incorporating auxiliary groups attached to $\mathrm{C}-2$ and $\mathrm{C}-12$. Compounds were screened for bioactivity in growth and barley endosperm-based bioassays.

Abstract | PDF (570 KB) $-\$ 25.00$ BuY How. | Supplementary Material (1.3 MB)

Phytochemical Study of Fagraea spp. Uncovers a New Terpene Alkaloid with Anti-inflammaiory Properties

Suciati, Lynette K. Lambert, Benjamin P. Ross, Myma A. Deseo and Mary J. Garson pp. 489-494

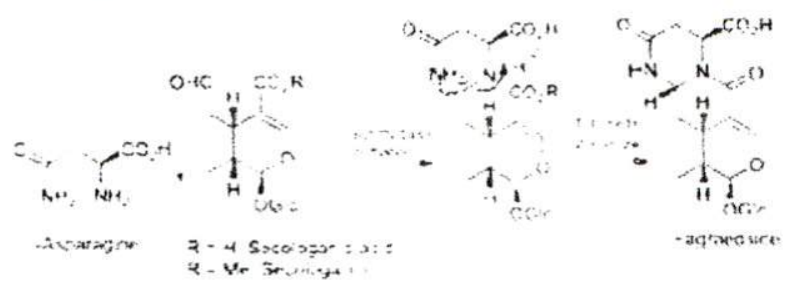

A new alkaloid fagraeoside, likely derived from the condensation of secologanin with L-asparagine, was isoiated from Fagraea racemose JACK ex WALL (Loganiaceae) along with secologanoside. Known lignans, flavonoids, iridoid and secoiridoid glucosides were isolated from throe cther species, namely f. blumei $G$. Don. F. auriculata Jack, Mal, and F. ceilanice Thunb. The anti-inflammatory, cytotoxic and anti-cholinesterase activity of selected compounds was evaluated.

Abstract | PDF $(241 \mathrm{~KB})-\$ 25.00$

BUY How : Supplementary Material (294 KB)

Wood Protection Properties of Quaternary Ammonium Spiroborate Esters Derived from Alkyl Tartrates

Jenny M. Carr, Peter J. Duggan, David G. Humphrey, James A. Platts and Edward M. Tyndalt pp. $495-502$

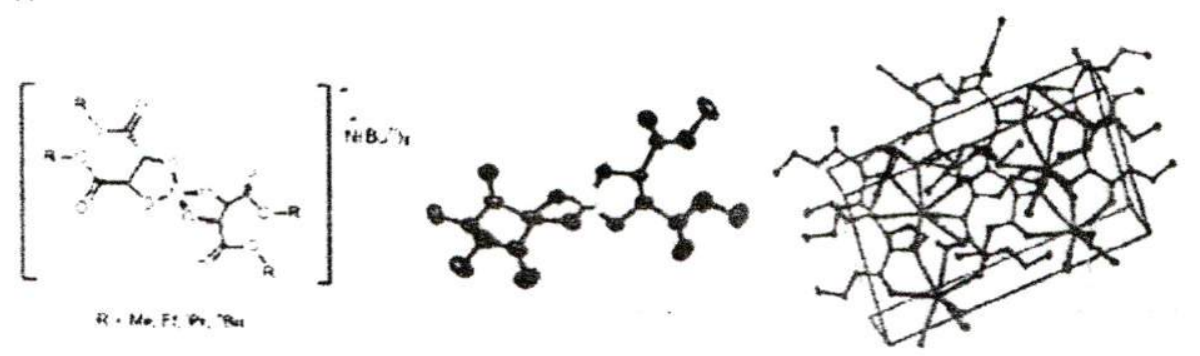




\title{
Phytochemical Study of Fagraea spp. Uncovers a New Terpene Alkaloid with Anti-Inflammatory Properties ${ }^{1}$
}

\author{
Suciati, ${ }^{\mathrm{A}, \mathrm{B}}$ Lynette K. Lambert, ${ }^{\mathrm{C}}$ Benjamin P. Ross, ${ }^{\mathrm{D}}$ \\ Myrna A. Deseo, ${ }^{E}$ and Mary J. Garson ${ }^{\text {A, F }}$ \\ ${ }^{A}$ School of Chemistry and Molecular Biosciences, The University of Queensland, \\ Brisbane, QId 4072, Australia. \\ ${ }^{B}$ Faculty of Pharmacy, Airlangga University, Surabaya, Indonesia. \\ ${ }^{C}$ Centre for Advanced Imaging, The University of Queensland, Brisbane, \\ Qld 4072, Australia.

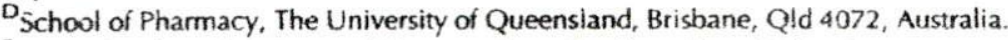 \\ ${ }^{E}$ Centre for Phytechemistry and Pharmacology, Southern Cross University, \\ PO Box 157, Lismore, NSW 2480, Australia. \\ ${ }^{F}$ Corresponding author. Email: m.garson@uq.edu.au
}

\begin{abstract}
Phytochemical investigation of the stem bark of $F$. racemosa JACK ex WALL (Loganiaceae) from East Java, Indonesia, has resuited in the isolation of a new alkaloid fagraeoside along with the iridoid glycoside secologanoside. Fagraeoside may be derived from the condensation of secologanin with L-asparagine, and represents a rare example of a terpene alkaloid in which the amino acid component is non-aromatic. Investigation of three additional species of Fagraea provided known lignans, iridoid or secoiridoid glycosides, and flavanol-6-C-glucosides, thas it is likely that iridoid and secoiridoid glucosides are chemotaxonomic markers for the Fagraea genus. Fagraeoside inhibited the production of prostaglandin $\mathrm{E}_{2}$ in $3 \mathrm{~T} 3$ murine fibroblasts $\left(\mathrm{IC}_{50} \sim 5.1 \mu \mathrm{M}\right)$, and was not cytotoxic to this cell line or to a P388 murine leukaemia cell line. Selected isolated compounds, including fagraeoside, showed low to moderate activity in anti-acetyicholinesterase screening.
\end{abstract}

Manuscript received: 20 November 2010.

Manuscript accepted: 6 January 2011.

\section{Introduction}

Fagraea (Loganiaceae) is a genus of shrubs or small trees consisting of $\sim 50$ species, which are distributed throughout Indo-Malaya, China, and Australia. Species of this genus often have large flowers and can live as an epiphyte in host trees with roots eventually reaching to the ground. ${ }^{[1,2]}$ Fagraea has been used as a traditional medicine in many parts of South East Asia, including in Cambodia, Ma!aysia, the Philippines, and in Vietnam. The leaves have been used mainly for their analgesic and antipyretic effects, while a decoction of the bark is used as an antimalarial, an antipy-etic, or as an anti-inflammator, agent. ${ }^{[3,4]}$

Previous studies on the chemistry of Fagraea spp. have identified lignans, including $(+)$-pinoresinol, $(+)$-epipinoresinol, $(+)$-lariciresinol, and (+)-isolariciresinol, and phenols from the root of $F$. racemosa JACK ex WALL collected in Sabah, Borneo, Malaysia. ${ }^{[S]}$ The methanolic extract of $F$. obovata leaves obtained from Jogfalls, Kamataka, India, contained the glycosyl flavone fagovatin. ${ }^{[4]}$ Other compounds including a benzyl alcohol derivative, di-O-methylcrenatin, the flavone C-glucoside swertisin and some iridoid glucosides, namely blumeosides $\mathrm{A}-\mathrm{D}$, were isolated from $F$. blumei $\mathrm{G}$ Don, ${ }^{[6]}$ while the alkaloid gentianine was isolated from the leaves and fruits of
F. fragrans. ${ }^{[7]}$ Over 50 volatile compounds have been isolated from the white flowers of $F$. berteriana, with these compounds responsible for the characteristic odor of the flower. ${ }^{[8]}$ We now report a study on constituents of stem bark from Fagraea spp. collected in Eas: Java, Indonesia which gave a new alkaloid, named by us as fagraeoside, together with eleven known compounds. The structures of the isolated compounds were decuiced on the basis of NMR spectroscopic data and mass spectrometry. The anti-inflammatory, cytotoxic, and antiacetylcholinesterase effects of selected metabolites have also been investigated.

\section{Results and Discussion}

Powdered, air-dried stem bark samples from four species of Fagraea were collected in East Java, Indonesia and extracted sequentially with hexanes, then $\mathrm{DCM}$ and finally $\mathrm{MeOH}$. The methanol extract from $F$. racemosa was purified by reverse phase flash chromatography followed by $\mathrm{C}_{18}$ HPLC yielding fagracoside (1), whose structure was established by ID and 2D NMR spectroscopy, and secologanoside (2), identified by comparison with literature data. ${ }^{\text {[9] }}$

For compound (i), HRESIMS revealed an intense ion at $\mathrm{m} / 2$ $469.1468[\mathrm{M}-\mathrm{H}]^{-}$, corresponding to a molecular formula of

${ }^{1}$ Dedicated to the memory of the late Professor Athel Beckwith, an outstanding Australian chemist. 
Table 1. NMR data $\left(\mathrm{D}_{2} \mathrm{O}\right)$ for fagraeoside

\begin{tabular}{|c|c|c|c|c|}
\hline Position & $\delta \hat{c}^{\hat{1}}$ & $\delta_{1 \mathrm{H}}, \mathrm{m}(\mathrm{J} \text { in } \mathrm{Hz})^{B}$ & $\cos Y^{c}$ & ${ }^{1} \mathrm{H}-{ }^{13} \mathrm{C} \mathrm{FMBC} C^{\mathrm{D}}$ \\
\hline 1 & 99.8 & $5.53, \mathrm{~d}(1.7)$ & 9 & $3,5,8,1^{\prime}$ \\
\hline 3 & 151.2 & $7.43, d(2.2)$ & 5 & $1,4,5,11$ \\
\hline 4 & 110.4 & - & - & - \\
\hline 5 & 26.6 & $3.10, \mathrm{~m}$ & $3,6 b$ & $3,6,7,9$ \\
\hline 6 & 33.2 & $\begin{array}{l}\text { a } 2.22 \text {, id }(12.8 .4 .0) \\
\text { b } 1.58, \text { ddd }(12.8,11.5,10.6)\end{array}$ & $\begin{array}{l}6 \mathrm{~b}, 7 \\
6 \mathrm{a}, 5,7\end{array}$ & $\begin{array}{l}4^{E}, 5,7^{E}, 9 \\
4^{E}, 5,7^{E}, 9\end{array}$ \\
\hline 7 & 66.2 & 5.24 , dd $(10.6,4.0)$ & $6 \mathrm{a}, 6 \mathrm{~b}$ & $5,6^{\mathrm{E}}, 11^{\mathrm{E}}, 2^{\prime \prime}$ \\
\hline 8 & 134.3 & 5.58, ddd $(17.1,10.1,9.9)$ & $9,10 \mathrm{a}, 10 \mathrm{~b}$ & $1,5,9$ \\
\hline 9 & 44.8 & $2.80, \mathrm{~m}$ & 1,8 & $1,4,5,8,10$ \\
\hline 10 & 123.5 & a 5.37 , dd $(17.1,1.4)$ & 8 & 8,9 \\
\hline $\begin{array}{l}11 \\
y^{\prime}\end{array}$ & $\begin{array}{l}168.3 \\
100.9\end{array}$ & - & - & - \\
\hline $2^{\prime}$ & $\begin{array}{r}100.9 \\
75.4\end{array}$ & $\begin{array}{l}\text { 4.83. } d(8.0) \\
3.28, d d(9.4,8.0)\end{array}$ & $\begin{array}{ll}2^{\prime} \\
y^{\prime} & 3^{\prime}\end{array}$ & $1,3^{\prime}, 5^{\prime}$ \\
\hline $3^{\prime}$ & $\begin{array}{l}75.4 \\
78.2\end{array}$ & $\begin{array}{l}\text { 3.28, dd }(9.4,8.0) \\
3.50, \mathrm{t}(9.4)\end{array}$ & $\begin{array}{l}l^{\prime}, 3^{\prime} \\
2^{\prime}, 4^{\prime}\end{array}$ & $\overline{z^{\prime} A^{\prime}}$ \\
\hline $4^{\prime}$ & 72.4 & $\begin{array}{l}3.50, \mathrm{t}(9.4) \\
3.40 \text { dd }(9.8,9.4)\end{array}$ & $\begin{array}{l}2,4 \\
3^{\prime}, 5^{\prime}\end{array}$ & $\begin{array}{l}2^{\prime}, 4^{\prime} \\
3^{\prime}, 5^{\prime}, 6^{\prime}\end{array}$ \\
\hline $5^{\prime}$ & 79.1 & $\begin{array}{l}3.40, \text { dd }(9.8,9.4) \\
3.51 \text {, ddd }(9.8,6.0 .2 .1)\end{array}$ & $4^{\prime}, 6^{\prime} \mathrm{b}$ & $\begin{array}{l}3^{\prime}, 5^{\prime}, 6^{\prime} \\
4^{\prime}\end{array}$ \\
\hline \multirow{2}{*}{$6^{\prime}$} & 63.5 & a $3.92, \mathrm{dd}(12.4 .2 .1)$ & $6^{\prime} \mathrm{b}$ & $4^{\prime}$ \\
\hline & & b 3.72, dd $(12.4,6.0)$ & $6^{\prime} \mathrm{a}, 5^{\prime}$ & $5^{\prime}$ \\
\hline $2^{\prime \prime}$ & 175.5 & - & - & - \\
\hline \multirow[t]{2}{*}{$3^{\prime \prime}$} & 36.0 & a 2.83 , dd $(16.6,7.3)$ & $3^{\prime \prime} \mathrm{b}, 4^{\prime \prime}$ & $2^{\prime \prime}, 4^{\prime \prime}, 5^{\prime \prime}$ \\
\hline & & b $2.70, \mathrm{dd}(16.6,6.2)$ & 3"a, 4" & $2^{\prime \prime}, 4^{\prime \prime}, 5^{n \prime}$ \\
\hline $4^{\prime \prime}$ & 56.3 & $4.89, \mathrm{dd}(7.3,6.2)$ & 3"a, $3^{\prime \prime} \mathrm{b}$ & $7,11,2^{\prime \prime}, 3^{\prime \prime}, 5^{\prime \prime}$ \\
\hline $5^{\prime \prime}$ & 178.9 & - & - & - \\
\hline
\end{tabular}

AData recorded at $100 \mathrm{MHz}$, referenced to TSP at $0.0 \mathrm{ppm}$

${ }^{3}$ Data recorded at $750 \mathrm{MHz}$, referenced to $\mathrm{H}_{2} \mathrm{O}$ at $4.77 \mathrm{ppm}$.

Data recorded at $500 \mathrm{MHz}$

Data recorded at $750 \mathrm{MHz}$ with ${ }^{n} J_{\mathrm{Cu}} 8 \mathrm{~Hz}$

${ }^{\mathrm{E}}$ Additional correlations from dats recorded at $750 \mathrm{MHz}$ with ${ }^{n} J_{\mathrm{Cn}} 4 \mathrm{~Hz}$.

$\mathrm{C}_{20} \mathrm{H}_{26} \mathrm{~N}_{2} \mathrm{O}_{11}$. The ${ }^{13} \mathrm{C}$ NMR data (Tabie 1) were acquired in $\mathrm{D}_{2} \mathrm{O}$ and revealed 20 carbons, including three carbonyl signals at $\delta_{\mathrm{C}} 168.3,175.5$, and 178.9. The ${ }^{1} \mathrm{H}$ NMR data, also in $\mathrm{D}_{2} \mathrm{O}$, showed features typical of a $\beta$-glucose residue, including an anomeric proton at $\delta_{\mathrm{H}} 4.83\left(\mathrm{H}-1^{\prime}\right)$ with the corresponding carbon at $\delta_{\mathrm{C}} 100.9$ by HSQC, a pair of muitiplets (dd) at $\delta_{\mathrm{H}} 3.92$ and $\delta_{\mathrm{H}} 3.72$ for $\mathrm{H}-6^{\prime}$, and resonances for four methine protons between $\delta_{\mathrm{H}} 3.51$ and 3.28. A full assignment of the glucose moiety was provided from TOCSY, DQF-COSY, and nOe data

Other structural fearures resembled a secoiridoid fragment, and included an alkene proton at $\delta_{\mathrm{H}} 7.43(\mathrm{H}-3)$ with the corresponding carbons at $\delta_{\mathrm{C}} 151.2(\mathrm{C}-3)$ and $110.4(\mathrm{C}-4)$, an acetal proton at $\delta_{\mathrm{H}} 5.53(\mathrm{H}-1)$ correlated with a carbon at $\delta_{\mathrm{C}} 99.8$ by HSQC, and resonances for three vinylic protons at $\delta_{\mathrm{H}} 5.58$ $(\mathrm{H}-8), 5.37(\mathrm{H}-10 \mathrm{a})$, and $5.30(\mathrm{H}-10 \mathrm{~b})$, with the corresponding alkene carbons at $\delta_{\mathrm{C}} 134.3(\mathrm{C}-8)$ and $123.5(\mathrm{C}-10){ }^{2}$ A proton sicna! at $\delta_{\mathrm{H}} 5.24(1 \mathrm{H}, \mathrm{dd}, J=10.6,4.0, \mathrm{H}-7)$ linked to a carbon at $\delta_{\mathrm{C}} 66.2(\mathrm{~d}, \mathrm{C}-7)$ supported e:ther an $\alpha$-aminoacyl centre or an $N, N$ acetal. The $\mathrm{H}-7$ signal could be linked by DQFCOSY and/or TOCSY correlations to signals at $\delta_{\mathrm{H}} 2.22$ $(\mathrm{H}-6 \mathrm{a}), \delta_{\mathrm{H}} 1.58(\mathrm{H}-6 \mathrm{~b}), \delta_{\mathrm{H}} 3.10(\mathrm{H}-5)$, and $\delta_{\mathrm{H}} 2.80(\mathrm{H}-9)$. $\mathrm{HSQC}$ correlations then located $\mathrm{C}-5, \mathrm{C}-6, \mathrm{C}-7$, and $\mathrm{C}-9$, while geHMBC correlations (Fig. la) from $\mathrm{H}-3$ and from $\mathrm{H}-7$ to an amide-like carbonyl at $\delta_{C} 168.3$ identified the remaining 'secoiridoid' carbon C-11. The HMBC correlation between $\mathrm{H}-1^{\prime}$ and $\mathrm{C}-1$ confirmed the position of the glucose moiety. When the ${ }^{1} \mathrm{H}$ NMR spectrum of fagraeoside was run in DMSO$d_{6}$, a broad NH singlet at $\delta_{\mathrm{H}} 7.82$ was detected which gave $\mathrm{HMBC}$ correlations to $\mathrm{C}-7$ and NOESY correlations to $\mathrm{H}-7$.
The four remaining carbons were two carbonyls $\left(\delta_{\mathrm{c}} 175.5\right.$, and 178.9), a methylene $\left(\delta_{\mathrm{C}} 36.0\right)$ and a methine $\left(\delta_{\mathrm{C}} 56.3\right)$. There were three unassigned proton signais: an $\alpha$-aminoacyl proton at $\delta_{\mathrm{H}} 489\left(1 \mathrm{H}, \mathrm{dd}, J=7.3,6.2, \mathrm{H}-4^{\prime \prime}\right)$ linked to the carbon at $\delta_{\mathrm{C}} 56.3$ by HSQC, and methylene protons at $\delta_{\mathrm{H}} 2.83(1 \mathrm{H}$, dd, $J=16.6,7.3, \mathrm{H}^{\prime \prime} 3^{\prime \prime}$ a) and $2.70(1 \mathrm{H}, \mathrm{dd}, J=16.6,6.2$, $\mathrm{H}-3^{\prime \prime} \mathrm{b}$ ), linked to the signal at $\delta_{\mathrm{C}} 36.0$ by HSQC. HMBC correlations were from $\mathrm{H}-4^{\prime \prime}$ to $\mathrm{C}-3^{\prime \prime}$, to $\mathrm{C}-7$, and notably to the amide $\mathrm{C}-11$ as well as to the two carbonyls at $\delta 175.5\left(\mathrm{C}-2^{\prime \prime}\right)$ and $178.9\left(C-5^{\prime \prime}\right)$. H- $3^{\prime \prime}$ showed correlations to $C-2^{\prime \prime}, C-5^{\prime \prime}$, as well as to $\mathrm{C}-4^{\prime \prime}$, and $\mathrm{H}-7$ at $\delta_{\mathrm{H}} 5.24$ showed correlations to $\mathrm{C}-2^{\prime \prime}$ and, as mentioned, to $\mathrm{C}-11$, while the $\mathrm{NH}$ signal showed a correlation to $\mathrm{C}-3^{\prime \prime}$. These data fitted for a tetrahydropyrimid$4(3 \mathrm{H})$-one ring constructed biosynthetically from the condensation of an asparagine unit onto the secoiridoid framework (Fig. 2). An alternative tetrahydropyrimid-4(3H)-one structure with the free carboxyl group at $\mathrm{C}-3^{\prime \prime}$ instead of at $\mathrm{C}-\mathrm{A}^{\prime \prime}$ was both inconsistent with the ${ }^{1} \mathrm{H}$ and ${ }^{13} \mathrm{C}$ chemical shifts of $\mathrm{C}-3^{11}$ and $\mathrm{C}-4^{\prime \prime}$ and would be biosynthetically-unprecedented. The tetrahydropyrimid-4(3H)-one jadomycin $N$ with $\delta_{\mathrm{C}} 66.95$ for the $N, N$ acetal centre, a value comparable to that shown by $C-7$ of 1 , has recently been isolated from cultures of Streptomyces venezuelae ISPS230 grown on L-asparagine as sole nitrogen source. ${ }^{[10]}$

The relative configuration was deduced from NOESY data (Fig. 1b) which showed correlations from $\mathrm{H}-5$ to $\mathrm{H}-7$ and to $\mathrm{H}-9$, and between $\mathrm{H}-7$ and the diastereotopic proton at $\delta_{\mathrm{H}} 2.83$ $\left(\mathrm{H}-3^{\prime \prime} \mathrm{a}\right)$. Modelling of fagraeoside was undertaken using Chem Bio 3D ultra 12.0 (Cambridge); using MM2 software for energy minimization to an RMS gradient of 0.100 , and revealed a

\footnotetext{
${ }^{2}$ Standard secoiridoid numbering used throughout.
} 
(a)

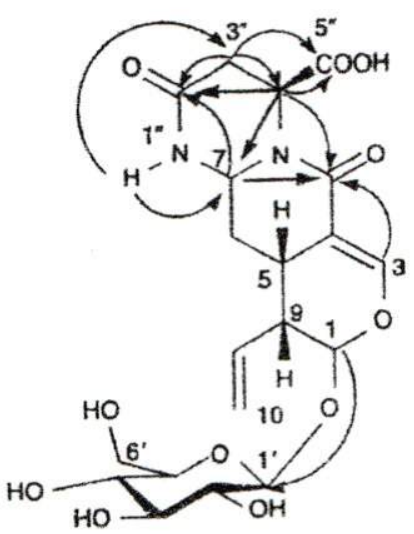

(b)

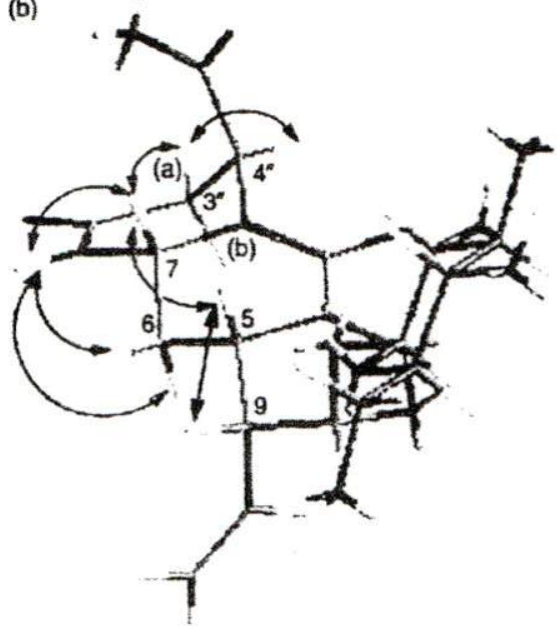

Fig. 1. Structure of fagraeoside (1) showing (a) important HMBC correlations observed in $d_{6}$-DMSO; (b) MM2 minimised model showing selected nOe or NOESY correlations observed in $d_{6}$-DMSO (doubleheaded arrows).

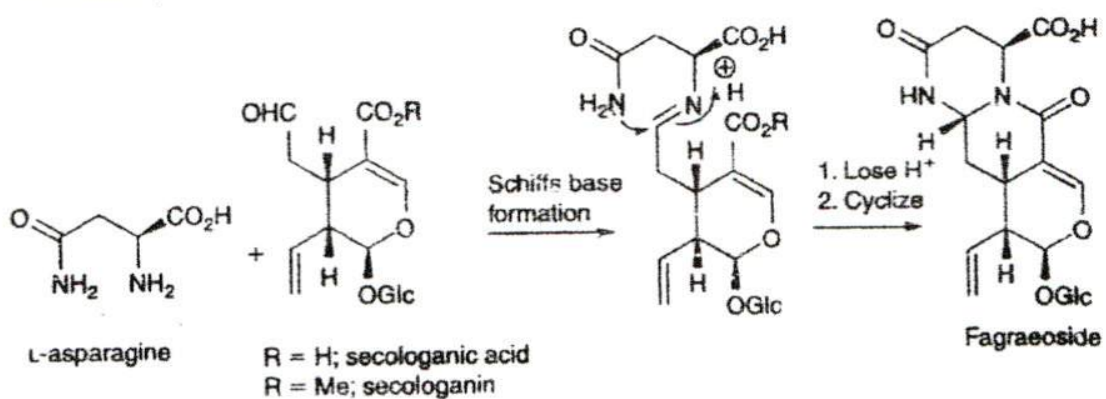

Fig. 2. Proposed biosynthesis of fagraeoside from a secologanin-derived precursor and from L-asparagine.

flattened chair for the tetrahydropyrimidinone ring. In the ${ }^{1} \mathrm{H}$ NMR in $\mathrm{D}_{2} \mathrm{O}, \mathrm{H}-4^{\prime \prime}$ appeared as a doublet of doublets with $J$ values of $7.3 \mathrm{~Hz}$ to $\mathrm{H}_{-1} 3^{\prime \prime} \mathrm{a}$ and of $6.2 \mathrm{~Hz}$ to $\mathrm{H}-3^{\prime \prime} \mathrm{b}$, matching the observed dihedral angles in 1 between $\mathrm{H}-4^{\prime \prime}$ and $\mathrm{H}-3^{\prime \prime}$ a $\left(56.7^{\circ}\right)$ and $\mathrm{H}-3^{\prime \prime} \mathrm{b}\left(61.8^{\circ}\right)$. When the $\mathrm{C}-4^{\prime \prime}$ epimer was modelled, the measured dibedral angles were respectively $64.6^{\circ}$ and $175.9^{\circ}$ which would have led to one large $J$ value for the $\mathrm{H}-4^{\prime \prime}$ signal. Although such data must be used with care, the absence of a NOESY correiation between $\mathrm{H}-\mathrm{T}$ and $\mathrm{H}-\mathrm{A}^{\prime \prime}$ was also consistent with the proposed relative configuration. In the $\mathrm{C}-4$ epimer these protons are on the same face with an inter proton distance of $2.6 \dot{\mathrm{A}}$, whereas in 1 , they are on the opposite face, ard thus $3.9 \dot{\mathrm{A}}$ apart.

Another metabolite isolated from $F$. racemosa was (-) secologanoside $(2)^{[9]}$ which was easily recognised by comparison of its NMR data with the literature. The presence of a D-glucose moiety in 1 and in $\mathbf{2}$ was confirmed by acid hydrolysis, derivatization with TFAA, and enantioselective gas chromatography. ${ }^{[1]}$ The absolute configuration shown for 1 is further supported by its co-isolation with secologanoside, and by the proposed role of secologanin in the biosynthetic pathway of 1 . Consequently, $\mathrm{t}$-asparagine is implicated in the biosynthesis of 1.

Three other species of Fagraea were investigated for their chemistry. Stem bark from the species $F$. blumei yielded first, from the methanolic fraction, di- $O$-methylcrenatin (3). ${ }^{[12]}$ potalioside B $(4),{ }^{[12]}$ the iridoid glucoside adoxosidic acid $(5),{ }^{[6,13]}$ and its methyl ester derivative adoxoside (6); $;^{[14]} \mathrm{sec}-$ ond, from the DCM extract, $(+)$-pinoresinol $(7)^{[5,15.16]}$ and salicifoliol (8). ${ }^{[16]} \mathrm{Di}-O$-methylcrenatin (3), adoxosidic acid (5), and adoxoside (6) have all been previously reported from F. blumei..$^{[6]}$ The iridoid glucoside loganic acid $(9)^{[17}$ and the secoiridoid glucoside sweroside $(10)^{[18]}$ were isolated from $F$. auriculata together with potalioside B (4). An extract from $F$. ceilanica yielded two hydroxyflavanol C-glycosides whose NMR data matched those of taxifolin-6-C-ghucoside (11) ${ }^{[19]}$ and aromadendrin-6-C-glucoside (12) ${ }^{[20]}$ together with secologanoside (2) and loginic acid (9) (Fig. 3).

In view of the traditional usage of Fagraea berk as an antiinflammatory and antipyretic agent, compound 1 was screened for cytotoxicity and anti-inflammatory activity. ${ }^{[21]}$ Although 1 inhibited the production of $\mathrm{PGE}_{2}$ in $3 \mathrm{~T} 3$ murine fibroblasts $\left(\mathrm{IC}_{50}\right.$ $5.1 \mu \mathrm{M}$ ), an atypical dose response curve was obtained (Fig. 4). even on repeat screening. Acetyl salicylic acid $\left(\mathrm{IC}_{50} 2.6 \mu \mathrm{M}\right)$ was used as a positive control. The observed anti-inflammatory activity did not appear to be a cytotoxic response since the compound lacked cytotoxicity to the 3T3 cells, and also to a P388 murine leukaemia cell line, when compared with chlerambucil as a reference compound. Additional testing is required to understand these effects. Although several iridoid glycosides show useful anti-inflammatory activity, there are few such reports for seco-iridoids. ${ }^{\{22,23\}}$ Compounds 1, 2, 4, 7-9, 11. 


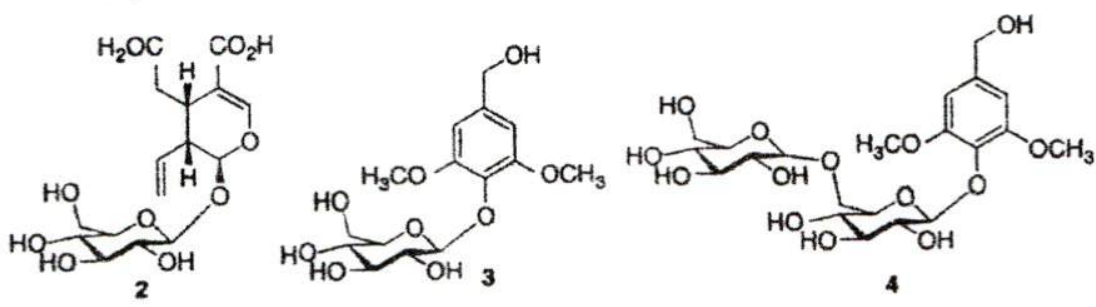<smiles>COc1cc([C@H]2OC[C@@H]3[C@@H]4CO[C@@H](c5ccc(O)c(OC)c5)O[C@@H]4[C@H]23)ccc1O</smiles><smiles>COc1cc([C@H]2OC[C@H]3COC[C@H]23)ccc1O</smiles>

8

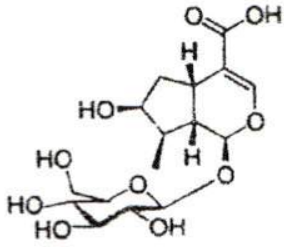

9

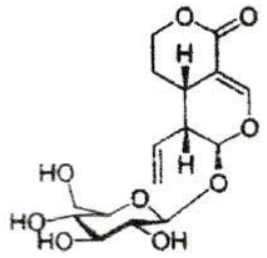

10<smiles>[R]c1cc([C@H]2Oc3cc(O)c(O)c(c3O)C(=O)C2O)ccc1O</smiles>

$11 \mathrm{R}=\mathrm{OH}$

$12 \mathrm{R}=\mathrm{H}$

Fig. 3. Secoiridoid glycoside, iriaioid glycoside, and lignan metaboirtes from Fagraea spp.

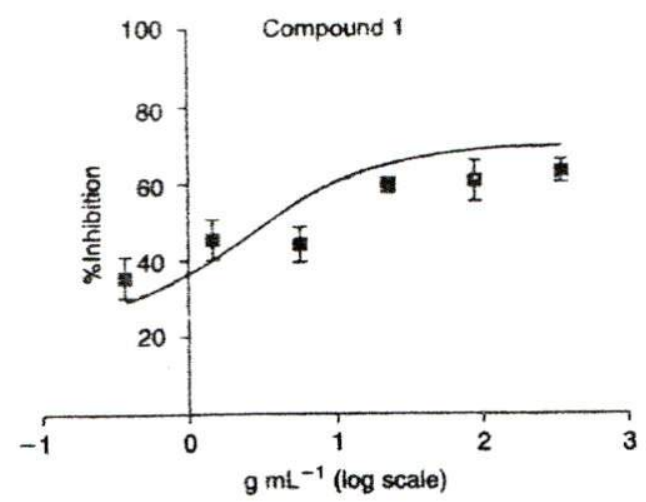

Fig. 4. Anti-inflarnmatory activity of fagraeoside against 3T3 murine fibroblast cells.

and 12 were also screened for anti-acetylcholinesterase activity in an assay using Ellman's reagent, 5,5'-dithiobis-(2-nitrobenzoic acid) (DTNB), ${ }^{[24]}$ with the data quantified by detection at $415 \mathrm{~nm}$ using a microplate reader. ${ }^{[24,25]}$ The inhibition observed for all cight metabolites at $100 \mu \mathrm{g} \mathrm{mL}^{-1}$ was similar to the inhibition found for galanthamine $\mathrm{HBr}$ salt at $0.184 \mathrm{~g} \mathrm{mLL}^{-1}$, which indicated that the metabolites are relatively weak inhibitors of acetyicholinesterase.

\section{Conclusion}

One of the largest group of plant alkaloids are the indole alkaloids formed from the condensation of secologanin with the aromatic amino acid tryptophan. This paper has described the structure and stereochemistry of a novel alkaloid that may be derived in Nature from the condensation of secologanin with the amino acid $\mathrm{t}$-asparagine. There are remarkably few reports of terpene alkaloids in the literature in which the amino acid component is non-aromatic. Machida et al. $(2002)^{[26]}$ have described $L$-phenylalaninosecologanin, presumably formed by enzymatic reduction of the Schiffs base product of secologanin and L-phenylalanine, from Lonicera japonica Thunb. Our investigations on the secondary metabolites of the genus Fagraea have revealed the presence of iridoid and secoiridoid glycosides in all four species studied, and when considered together with an earlier literature report ${ }^{[6]}$ suggest that such compounds may be chemotaxonomic markers for the genus. 


\section{Experimental \\ General}

Reverse phase HPLC was conducted on an Agilent 1100 series instrument with variable wavelength UV detector set at 240 or at $254 \mathrm{~nm}$ or on a Shimadzu LC-20AT with a low temperatureevaporative light scattering detector (EL.S.D.-LT) fitted with a semi-preparative Waters HPLC column ( $\mu$ Bondapak $\mathrm{C}_{18}$ $7.8 \times 300 \mathrm{~mm}$ ) or a Phenomenex column (Gemini 5 micron $10 \times 250 \mathrm{~mm}$ ). Positive or negative ion electrospray mass spectra (LRESMS) were determined using a Bruker Esquire HCT instrument or (HRESMS) on a MicroT of $Q$ instrument, each with a standard ESI source. Optical rotation $[\alpha]_{D}$ measurements were taken on a Perkin-Elmer $241 \mathrm{MC}$ or a JASCO P-1010 polarimeter. The ${ }^{1} \mathrm{H}$ and ${ }^{13} \mathrm{C}$ NMR data were measured on Bruker Avance 400,500 , or $750 \mathrm{MHz}$ spectrometers at $298 \mathrm{X}$. Normal phase and reverse phase thin-layer chromatography were performed on Merck Art 5554 and 5559 aluminium backed plates precoated with silica gel Merk Kieselgel 60 F254, respectively. Normal phase flash column chromatography was undertaken on Scharlau silica gel $60,0.04-0.06 \mathrm{~mm}$ (230-400 mesh ASTM), while reverse phase flash column chromatography was carried out on silica gel prepared using the method developed by Evans et al. ${ }^{[27]}$ Acetylcholinesterase inhibition assay measurements were performed using a Bio-Rad Model 550 microplate reader at $415 \mathrm{~nm}$.

\section{Collection, Extraction, and Isolation}

Stem bark of $F$. blumei G.Don (SC0106) was collected in Malang, East Java, Indonesia on 16 November 2006. Stem bark of $F$. ceilanica Thunb (SC0206) and $F$. racemosa JACK ex WALL (voucher sample SCC306) was collected on 16 November 2006 from Purwodadi Botanic Garden, East-Java, Indonesia. A methanolic extract of the stem bark of $F$. auriculata Jack, Mall (sample collected 26 February 2001; voucher FU0101) was a generous gift from Dr Achmad Fuad, Faculty of Pharmacy, Airlangga University, Surabaya, Indonesia. All plants were identified by staff of Purwodadi Botanic Garden, East Java, Indonesia; voucher samples are stored in the Faculty of Pharmacy, Airlangga University. Plant materials were chopped and air-dried at room temperature for 5 days and then powdered using a blender.

Powdered stem bark of $F$. racemosa $(530 \mathrm{~g})$ was macerated with hexanes $(3 \times 24 \mathrm{~h})$, then with $\mathrm{DCM}$, and finally by $\mathrm{MeOH}$. The methanolic extract ( 18 g $)$ was fractionated by vacuum liquid chromatography, with a gradient of $\mathrm{CHCl}_{3}, \mathrm{MeOH}$, and $\mathrm{H}_{2} \mathrm{O}$ in increasing polarity, and afforded 9 fractions. Fraction 8 , namely FRM8, was then partitioned by NP flash chromatography, using EtOAc, $\mathrm{MeOH}$, and $\mathrm{H}_{2} \mathrm{O}$ in order of increasing polarity. The first three fractions, namely FRM801, 802, and 803 eluting in EtOAc/McOH (9:1), EtOAc/MeOH/ $\mathrm{H}_{2} \mathrm{O}(9: 1: 1)$, and EtOAc/ $\mathrm{MeOH} / \mathrm{H}_{2} \mathrm{O}(8: 2: 1)$, respectively contained secologanoside (2) $(134.6 \mathrm{mg})$. The fourth fraction, FRM804, was subjected to flash chromatography on $\mathrm{SiO}_{2}$ using a solvent mixture of EtOAc/ $\mathrm{MeOH} / \mathrm{H}_{2} \mathrm{O}(8: 2: 1)$, followed by EtOAc/ $/ \mathrm{MeOH} / \mathrm{H}_{2} \mathrm{O}(5: 5: 1)$ and yielded 9 fractions. Fractions 7 and 8 , namely FRM8047 and FRM8048, were then subjected to RP-HPLC using a gradient of $0-50 \% \mathrm{MeOH}$ in $\mathrm{H}_{2} \mathrm{O}$ for 30 min, with UV detection at $240 \mathrm{~nm}$, and flowrate $1.5 \mathrm{~mL} \mathrm{~min}{ }^{-1}$. The component eluting at $20.9 \mathrm{~min}$ was fagraeoside (1) $(3.5 \mathrm{mg}$ ).

Powdered stem bark of $F$. blumei $(1 \mathrm{~kg})$ was macerated in hexanes, followed by $\mathrm{DCM}$ and $\mathrm{MeOH}$ using the same procedure as $F$. racemosa. A portion of the $\mathrm{MeOH}$ extract $(382 \mathrm{mg}$ ) was chromatographed on RP-silica gel using a solvent gradient from 0 to $100 \% \mathrm{MeOH}$ in $\mathrm{H}_{2} \mathrm{O}$. A fraction eluting in $0-20 \% \mathrm{MeOH} /$ $\mathrm{H}_{2} \mathrm{O}$ contained di- $\mathrm{O}$-methylcrenatin $(3)(3.7 \mathrm{mg})$, potalioside $\mathrm{B}$ (4) (1.4 mg), and a mixture of adoxosidic acid (5) ( $3.4 \mathrm{mg}$ ) and adoxoside (6), which were further purified by RP-HPLC $(0-50 \%$ $\mathrm{MeOH}$ in $\mathrm{H}_{2} \mathrm{O}$ for $60 \mathrm{~min}$, detection at $254 \mathrm{~nm}$ ). The DCM extract $(11.8 \mathrm{~g}$ ) was chromatographed on kieselgel $60 \mathrm{H}$ using hexanes, $\mathrm{DCM}$, and $\mathrm{MeOH}$ in order of increasing polarity, followed ky column chromatography on Diaion HP-20, using a solvent gradient $\left(20 \% \mathrm{H}_{2} \mathrm{O}\right.$ in $\mathrm{MeOH}$ to $\left.100 \% \mathrm{MeOH}\right)$ yielding 5 fractions. Fraction 1 was then subjected to RP-HPLC $(50 \%$ $\mathrm{MeOH}$ in $\mathrm{H}_{2} \mathrm{O}$ for $50 \mathrm{~min}$, detection at $254 \mathrm{~mm}$ ) to afford $(+)$-pinoresinol $(7)(3.8 \mathrm{mg})$ and salicifoliol $(8)(1.2 \mathrm{mg})$.

Extraction of powdered stem bark of $F$. auriculata was undertaken using the same procedure employed for $F$. racemosa and $F$. blumei. The $\mathrm{MeOH}$ extract ( $368 \mathrm{mg}$ ) was subjected to RP-flash colurno chromatography with a solvent gradient from 0 to $100 \% \mathrm{MeOH}$ in $\mathrm{H}_{2} \mathrm{O}$, and yielded 19 fractions. Fraction 4 was further purified by RP-HPLC with a gradient of 20 to $30 \%$ $\mathrm{MeOH}$ in water over $60 \mathrm{~min}$ to afford loganic acid (9) $(1.16 \mathrm{mg})$. Fraction 5, eluting in $20 \% \mathrm{MeOH} / \mathrm{H}_{2} \mathrm{O}$ contained potalioside $\mathrm{B}$ (4) $(8.79 \mathrm{mg})$, while fraction $6\left(50 \% \mathrm{MeOH} / \mathrm{H}_{2} \mathrm{O}\right)$ afforded sweroside (10) (33.9 mg).

Stem bark of $F$. ceilanica ( $488 \mathrm{~g}$ ) was extracted in the same way. A portion of the methanolic exiract $(3.9 \mathrm{~g})$ was partitioned by RP-flash chromatography using a solvent gradient from 9 to $100 \%$ MeOFi in $\mathrm{H}_{2} \mathrm{O}$. Repeated RP-1lash chromatography was undertaken on a fraction eluting in $100 \% \mathrm{H}_{2} \mathrm{O}$, followed by senii preparative RP-TLC with $\mathrm{MeOH} / \mathrm{H}_{2} \mathrm{O}(3 / 7)$ to obtain five fractions. Fractions 2 and 3 were further purified by RP-HPLC (15-50\% MeOH in $\mathrm{H}_{2} \mathrm{O}$ containing $0.1 \%$ TFA for $30 \mathrm{~min}$, detection at $254 \mathrm{~nm}$ ) to give taxifolin-6-C-glucoside (11) $(22.9 \mathrm{mg}$ ) from fraction 2 , and aromadendrin- $6-C$-glucoside (12) (14.1 mg), loganic acid (9) $(5.8 \mathrm{mg})$, and secologanoside (2) $(14.1 \mathrm{mg})$ from fraction 3 .

Fagraeoside (1): Pale yellow amorphous solid $(3.5 \mathrm{mg})$; $[\alpha]_{\mathrm{D}}^{23}-38.6\left(c \quad 0.57, \mathrm{H}_{2} \mathrm{O}\right)$; UV $\left(\mathrm{H}_{2} \mathrm{O}\right) \lambda_{\max }(\log \varepsilon) 241$ (3.53) $\mathrm{nm} ;{ }^{1} \mathrm{H}$ and ${ }^{13} \mathrm{C} N M R\left(\mathrm{D}_{2} \mathrm{O}, 750\right.$ and $\left.100 \mathrm{MHz}\right)$, see Table 1; 'H NMR (DMSO- $\left.d_{6}, 750 \mathrm{MHz}\right) \delta 7.82(1 \mathrm{H}$, br s, NH), 7.28 ( $1 \mathrm{H}, \mathrm{d}, J=2.4, \mathrm{H}-3), 5.47$ (1H, ddd, $J=17.2,10.3,10.0$, H-8), $5.36(1 \mathrm{H}, \mathrm{d}, J=1.7, \mathrm{H}-1), 5.30(1 \mathrm{H}, \mathrm{dd}, J=17.1,2.0$, $\mathrm{H}-10 \mathrm{a}), 5.22(1 \mathrm{H}, \mathrm{dd}, J=10.3,2.0, \mathrm{H}-10 \mathrm{~b}), 5.19(1 \mathrm{H}, \mathrm{dd}$, $J=11.6,3.0, \mathrm{H}-7), 4.90\left(1 \mathrm{H}, \mathrm{br} \mathrm{d}, J=6.8, \mathrm{H}-4^{\prime \prime}\right), 4.51(1 \mathrm{H}, \mathrm{d}$, $\left.J=8.0, \mathrm{H}-1^{\prime}\right), 3.68\left(1 \mathrm{H}, \mathrm{m}, \mathrm{H}-6^{\prime} \mathrm{a}\right), 3.42\left(1 \mathrm{H}, \mathrm{m}, \mathrm{H}-6^{\prime} \mathrm{b}\right), 3.14(2 \mathrm{H}$, $\mathrm{m}, \mathrm{H}-3^{\prime}$ overlapping with $\left.\mathrm{H}-5^{\prime}\right), 3.03\left(1 \mathrm{H}, \mathrm{m}, \mathrm{H}-4^{\prime}\right), 2.98(1 \mathrm{H}, \mathrm{m}$, $\left.\mathrm{H}-2^{\prime}\right), 2.85(1 \mathrm{H}, \mathrm{m}, \mathrm{H}-\mathrm{S}), 2.72\left(\mathrm{HH}, \mathrm{d}, J=16.0, \mathrm{H}-3^{\prime \prime} \mathrm{a}\right), 2.62(1 \mathrm{H}$, $\mathrm{m}, \mathrm{H}-9), 2.17\left(1 \mathrm{H}, \mathrm{dd}, J=16.0,6.8, \mathrm{H}-3^{\prime \prime} \mathrm{b}\right), 2.00(1 \mathrm{H}, \mathrm{m}, \mathrm{H}-6 \mathrm{a})$ $1.20(\mathrm{iH}, \mathrm{m}, \mathrm{H}-6 \mathrm{~b}) ;{ }^{13} \mathrm{C}$ NMR (DiMSO-d $6,750 \mathrm{MHz}$, partial data from YMBC) $\delta 161.8(\mathrm{C}-11), 146.6(\mathrm{C}-3), 132.9(\mathrm{C}-8), 119.8(\mathrm{C}$ 10), $107.0(\mathrm{C}-4), 98.6\left(\mathrm{C}-1^{\prime}\right), 95.4(\mathrm{C}-1), 77.1\left(\mathrm{C}-5^{\prime}\right), 76.7\left(\mathrm{C}-3^{\prime}\right)$, $72.8\left(\mathrm{C}-2^{2}\right), 69.8\left(\mathrm{C}-4^{\prime}\right), 62.6(\mathrm{C}-7), 61.0\left(\mathrm{C}-6^{\prime}\right), 50.6\left(\mathrm{C}-4^{\prime \prime}\right), 42.0$ (C-9), $34.4\left(\mathrm{C}-3^{\prime \prime}\right), 32.9$ (C-6), 23.8 (C-5); HRESIMS calcd. for $\mathrm{C}_{20} \mathrm{H}_{26} \mathrm{~N}_{2} \mathrm{O}_{11}, 469.1458$. Found: $m / z 469.1468[\mathrm{M}-\mathrm{H}]^{-}$

Secologanoside (2): Amorphous solid $(134.6 \mathrm{mg}) ;[\alpha]_{\mathrm{D}}^{20}$ $-98.3\left(c \quad 0.12, \mathrm{H}_{2} \mathrm{O}\right)$; UV $\left(\mathrm{H}_{2} \mathrm{O}\right) \lambda_{\max }(\log \varepsilon) 241(3.53) \mathrm{nm}$; the ${ }^{1} \mathrm{H}$ and ${ }^{13} \mathrm{C}$ NMR data were comparable with published values: ${ }^{\left[{ }^{[]}\right.}$LRESIMS $m / z 413.2[\mathrm{M}+\mathrm{Na}]^{+}$.

\section{Determination of Glucose Absolute Configuration}

The glucose moieties were characterised according to the method of Hayes et al. ${ }^{[11]}$ A sample of either fagraeoside 
( $0.74 \mathrm{mg})$ or secologanoside $(5.63 \mathrm{mg})$ was heated for $2 \mathrm{~h}$ at $100^{\circ} \mathrm{C}$ with $10 \% \mathrm{HCl}$ in $\mathrm{MeOH}(0.5 \mathrm{~mL})$. After cooling, the solution was concentrated under $\mathrm{N}_{2}$, then partitioned between water and $\mathrm{CHCl}_{3}(0.5 \mathrm{~mL})$, and the aqueous layer concentrated under $\mathrm{N}_{2}$. The residue was dissolved in a mixture of trifluoroacetic anhydride (TFAA)/DCM $(1 / 1,0.2 \mathrm{~mL})$ and then analysed by enantioselective chromatography (Chirasil-L-Val capillary column $(25 \mathrm{~m} \times 0.32 \mathrm{~mm} \times 0.2 \mu \mathrm{m})$, FID detection, carrier gas: helium, injector: $200^{\circ} \mathrm{C}$, colum flow $1.32 \mathrm{~mL} \mathrm{~min}^{-1}$, solit ratio: $56 / 0$, and oressure $40 \mathrm{kPa}$. Temperature program: initial temperature $50^{\circ} \mathrm{C}$ for $6 \mathrm{~min}$, raised at $4^{\circ} \mathrm{C} \mathrm{min}{ }^{-1}$ to a final temperature of $160^{\circ} \mathrm{C}$ for $5 \mathrm{~min}$ ). For comparison, standards were prepared from D- and L-glucose. Under these conditions, retertion times were L-Glc (26.22 and $29.88 \mathrm{~min}$ ), D-Glc ( 26.31 and $30.07 \mathrm{~min}$ ). For glycoside 1, peaks were observed at 26.30 and $30.06 \mathrm{~min}$, and for glycoside 2, peaks were observed at 26.26 and 30.02 min corresponding to D-glucose. Co-injection of either glucose pentarifluoroacetate product with the D-glucose reference standard gave in each case a single peak.

Evaluation of Anti-Inflammatory Activity and Cytotoxicity

The prostaglandin $E_{2}$ assay was undertaken using Swiss albino mouse embryo fibroblast celis 3T3 (American Type Culture Collection (ATCC), Manassas, VA) and a $\mathrm{PGE}_{2}$ enzyme inmuno-assay kit (Prostaglandin $E_{2}$ ELA kit-monoclonal, Cayman Chemical Co., Ann Arbor, MI, catalogue no. 5i41010) using acetyl salicylic acid as a positive control. Cytotoxicity in $3 \mathrm{~T} 3$ murine fibroblasts, and in P388D1 murine lymphoblasts (ATCC) was assayed using an ATPLite kit (PerkinElmer, Waitham, MA) with chlorambucil as a reference compound. Details of both assays have recently been published. ${ }^{[21]}$

\section{Evaluation of Acetylcholinesterase Inhibition}

Compounds were diluted in $\mathrm{MeOH}$ to a concentration of $1 \mathrm{mg} \mathrm{mL}^{-1}$. Galanthamine $\mathrm{HBr}$ salt was diluted in $\mathrm{MeOH}$ to a concentration of $100 \mu \mathrm{M}$. A solution of acetylthiocholine iodide in Millipore water $(15 \mathrm{mM}, 30 \mu \mathrm{L})$ was placed in each well of a 96-well plate. Then in sequence, 5, $5^{\prime}$-dithiobis-(2-nitrobenzoic aeid) in Millipore water $(3 \mathrm{mM}, 150 \mu \mathrm{L})$ and a buffer solution of bovine serum albumin $(0.1 \%)$ made up in TRIS- $\mathrm{HCl}$ buffer $(50 \mathrm{mM}, \mathrm{pH} 8.0,60 \mu \mathrm{L}$ ) were added, followed by the compound under assay $(30 \mu \mathrm{L})$ or by galanthamine $\mathrm{HBr}$ salt $(30 \mu \mathrm{L})$. A blank well container niethanol $(30 \mu \mathrm{I})$, instead of the compound under assay. The plate was shaken carefully to homogenize the mixture and the absorbance of individual wells at $415 \mathrm{~nm}$ was measured 10 times at intervals of $30 \mathrm{~s}$. Acetylcholinesterase solution $\left(0.22 \mathrm{U} \mathrm{mL}^{-1}, 30 \mu \mathrm{L}\right)$ was then added, the individual plates shaken and the absorbance measurements repeated a further 10 times. The experiments were done in quadnuplicate in three independent experiments.

\section{Accessory Publication}

The Accessory Publication contains copies of representative NMR spectra, including the ${ }^{1} \mathrm{H}$ and ${ }^{13} \mathrm{C}$ spectra of fagracoside (1) in $\mathrm{D}_{2} \mathrm{O}$, together with HMBC, NOESY, and ROESY data, and the ${ }^{1} \mathrm{H}$ and ${ }^{13} \mathrm{C}$ spectra of secologanoside (2) in $\mathrm{D}_{2} \mathrm{O}$. Also included are characterisation details and spectroscopic data of compounds 2-12. The Accessory Publication is availabie on the Journal's website.

\section{Acknowledgements}

The authors thank AusAID for the award of an Australian Development Scholarship, The Queensland Pharmacy Research Trust (Pharmaceutical Seciety of Australia, Qucensland branch) for financial support for the acetylcholinesterase inhibition assay, and Dr Achmad Fuad (Faculty of Pharmacy, Airiangga University, Surabaya, Indonesis) for the $F$. auriculata sample. We thank Dr Patricia Hayes for assistance with the enantioselective GC characterisation of D-glucose. Mr Graham McFarlane and Dr Tri Le assisted with MS and NMR measurements respectively.

\section{References}

[1] H. N. Ridley, The Flora of the Malay Peninsula, Vol. 21967 (L. Reeve \& Co., Ld.: London).

[2] B. J. Conn, Handbooks of the Flora of Papua New Guinea 1995 (Melbourne University Press: Melbourne).

[3] C. Wiart, Medicinal Plants of the Asia-Pacific: Drugs for the Future 2006 (World Scientific Publishing Ltd: Singapore).

[4] M. A. Qasim, S. K. Roy, M. Kamil, M. Hyas, Phytochemis:ry 1987, 26, 2871. doi: i0.1016/S0031-9422(00)83614-6

[S] E. Okuyama, K. Suzumura, M. Yamazaki, Chem. Pharm. Bull. (Tokyo) $1995,43,2200$.

[6] M. Cuendet, K. Hostettmann, O. Potterat, W. Dyatmiko, Helv. Chim. Acta 1997, 80, 1144. doi:10.1002/HLCA.19970800411

[7] A. S. C. Wan, Y. L. Chow, J. Pharm. Pharmacol. 1964, 16, 484.

[8] S. Hayashi, H. Kameoka, S. Hashimoto, K. Furukawa, T. Arai, J. Essent. Oil Res. 1955, 7, 505.

[9] I. Calis, O. Sticher, Phyrochemistry 1984, 23, 2539. doi:10.1016 S0031-9422(00)84094-7

[10] C. N. Borissow, C. L. Graham, R. T. Syvitski, T. R. Reid, J. Blay, D. L. Jakeman, ChemBioChem 2007, 8, 1198. doi:10.1002/CBIC. 200700204

[1i] P. Y. Hayes, R. Lehmann, K. Penman, W. Kitching, J. J. De Voss, Phyrochemistry 2009, 70, 105. doi:10.1016/3.PHYTOCHEM.2008. 10.019

[12] X. C. Li, H. N. FlSohly, L. A. Walker, A. M. Clark, Planta Med. 2005. 71, 977. doi:10.1055/S-2005-871233

[13] D. R. Gandner, J. Nanum, D. Zook, F. R. Sternitz, J. Nat. Prod. 1987, SO, 485. do: 10.1021/NP50051A024

[14] S. R. Jensen, B. J. Nielsen, Biochem. Syst. Ecol. 1979, 7, 103 doi: $10.1016 / 0305-1978(79) 90016-4$

[15] N. R. Guz, F. R. Stermitz, Phyrochemistry 2000, 54, 897. doi:10.1016] SO031-9422(00)00101-1

[16] A. G. Gonzalez, R. Estévez-Reyes, C. Mato, J. Nat. Prod. 1989, 52 , 1139. doi:10.1021/NP50065 A037

[17] L. Calis, M. F. Lahloub, O. Sticher, Helv. Chim. Acta 1984, 67, 160 doi: 10.1002 HLCA. 19840670119

[18] Y. Zhou, Y. T. Di, S. Gesang, S. L. Peng, L. S. Ding, Helv. Chim. Acta 2006, 89, 94. doi:10.1002/HLCA.200690016

[19] J. T. Mbafor, Z. T. Femum, R. Promsaithis, D. R. Sinson, M. S Tempesta, J. Nat. Prod 1989, S2, 417. doi:10.1021/NP50062A039

[20] Y. Hayashi, S. Ohara, T. Takahashi, Mokazai Gakkaishi 1987, 33, 511

[21] H. Wohimuth, M. A. Deseo. D. J. Brushett, D. R. Thompson, G. Mavfartane, L. M. Stevenson, D. N. Leach, J. Nat. Prod. 2010. 73, 743. doi:10.1021/NP900688R

[22] R. Tundis, M. R. Loizzo, F. Menichini, G. A. Statti, F. Menichini, Mini Rev. Med. Chem. 2008, 8, 399. doi:10.2174/138955708783955926

[23] B. Dinda, D. R. Chowdthury, B. C. Mohanta, Chem. Pharm. Bull. (Tokyo) 2009, 57, 765. doi:10.1248/CPB.57.765

[24] G. L. Ellman, K. D. Courtney, V. Andres, R. M. Featherstone, Biochem. Pharmacol. 1961, 7, 88. doi:10.1016/0006-2952(61) 90145-9

[25] I. K. Rhee, M. van de Meent, K. Ingkaninan, R. Verpoorte, J. Chromatogr. A 2001, 915,217 . doi: $10.1016 / S 0021-9673(01) 00624-0$

[26] K. Machida, H. Sasaki, T. rijima, M. Kikuchi, Chem. Pharm. Bull. (Toḱyo) 2002, 50, 1041. doi:10.1248/CPB.50.1041

[27] M. B. Evans, A. D. Dale, C. J. Little, Chromatographia 1980, 13, 5. doi:10.1007/BF02302709 


\section{Phytochemical Study of Fagraea}

spp. Uncovers a New Terpene Alkaloid with Anti-Inflammatory Properties

by Suciati Suciati

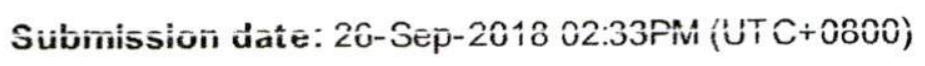

Submission ID: 1008647310

File name: fagraea-suci_2011.pdf (241.18K)

Word count: 5114

Character count : 24252 


\title{
Phytochemical Study of Fagraea spp. Uncovers a New Terpene Aikaioid with Anti-infiammatory Properties?
}

\author{
Suciati, ${ }^{\mathrm{A}, \mathrm{B}}$ Lynefte K. Lambert, ${ }^{\mathrm{C}}$ Benjamin P. Ross, ${ }^{\mathrm{D}}$ \\ Myrna A. Deseo, ${ }^{\mathrm{E}}$ and Mary J. Garson ${ }^{\mathrm{A}, \mathrm{F}}$ \\ ${ }^{A} S$ chool of Chemistry and Molecular Biosciences, The Universitv of Queensiand, \\ Brishane, Qld 4072, Australia.

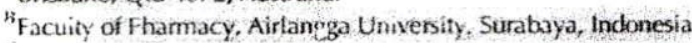 \\ Centr, for Advanced imaging, The Univer ity of Queensland, Brishare, \\ Oid 4072 , Australia. \\ DSchoot of Pharmacy, The University of Queensland, Brisbane, Q1d 4072, Australia. \\ 'Centre for Phytochemistry and Pharmacology, Southern Cross University, \\ PO Box 157, Lismore. NSW 2480. Australia.

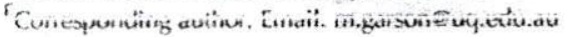

\begin{abstract}
Phytochemical investigation of the stem bark of $F$. racemosa JACK ex WALL (Loganiaceae) from East Java, Indonesia. has resulted in the isolation of a new athaloid fagraecside along with the iridoid glvcoside secologanoside. Fagraeoside may be derived from the condensation of secologanin with i-asparagine, and represents a rare example of a terpene alkaloid in which the amino acid component is non-aromatic. Investigation of three additional species of $F$ argraea provided known lignans, iridoid or secoiridoid glyeosides, and flavanol-6-C-glucosides, thus it is likely that iridoid and secoiridoid glucesides are chemotaxonomic markers for the Fagraea genus. Fagraeoside inhibited the production of prostaglandin $\mathrm{E}$ in $3 \mathrm{~T} 3$ murine fibroblasts $\left(\mathrm{IC} \mathrm{C}_{50} \sim 5.1 \mathrm{HM}\right)$, and was not cytotoxic to this cell line or to a P388 murine leukaemia cel

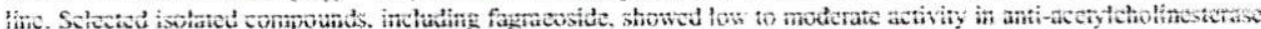
screening
\end{abstract}

Manuscript received: 20 November 2010.

Manuscript accepted: 6 January 2011.

\section{Intreduction}

Fagraea (Loganiaceae) is a genus of shrubs or small trees consisting of $\sim 50$ species, which are distributed throughout Indo-Malaya. China, and Australia. Species of this genus often have large flowers and can live as an epiphyte in host troes with roots eventually reaching to the ground. ${ }^{[1,2]}$ Fagraea has been used as a traditionat medicme m many parts of South East Asta. including in Cambodia, Malaysia, the Philippines, and in Victurn. The feaves have been used mainly for their analgesie and antipyretic effects, while a decoction of the bark is used as an antimalarial, an antipyretic, or as an anti-inflammatory agent. ${ }^{[3,4]}$

Previcus studies or: the chemistry of Fagruea spp. have identified lignans, including $(+)$-pinoresinol, $(+)$-epipinoresinol

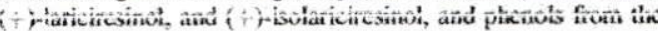
root of $F$ racemos JACK er WALt collected in Sabah, Bomeo. Malaysia. ${ }^{|S|}$ The methanolic extract of $F$. nbovatc leaves obtained from Jogfalts, Kamataka, India, contained the glycosyl flavone fagovatin. ${ }^{|A|}$ Other compounds including a benzyl alcohel derivative, oi- $O$-methylcrenatin, the flavone C-glucoside swentisin and some iridoid glucosides, namely blumeosides A-D, were isolated from $F$. bhumei G Don. ${ }^{[6]}$ while the alkatoid oentianine was isolated from the leaves and finlite of
F. frograns ${ }^{[7]}$ Over 50 volatile compounds have been isolated from the white flowers of $F$. berteriana, with these compounds responsible for the characteristic odor of the flower. ${ }^{[\mathrm{S}\}}$ We now report a study on constituems of stem bark from Fagrzaea spp. collected in East lava, Indonesia which gave a new alkaloid, named by us as fagraeoside, together with eleven known

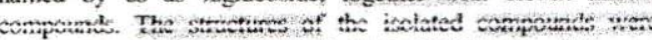
deduced on the basis of NMR spectroscopic data and mass spectrometiy. The anti-inflammatory, cytotoxic, and antiacetylcholinesterase effects of selected metabolites have also been investigated.

\section{Results and Discussion}

Powdered, air-dried stem bark samples from four species of

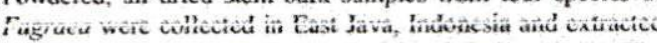
sequentially with hexanes, then DCM and finally MeOH. The methanol extract from $F$. racemosa was purified by reverse phase flash chromatography followed by $\mathrm{C}_{\mathrm{i} \times}$ HPLC yielding fagraeoside (1), whose structure was established by ID and 2D NMR spectroscopy, and secologanoside (2), identified by comparison with literature data. ${ }^{[9]}$

For compound ( 1 ), HRESIMS revealed an intense ion at $m / z$ $4601468 \mathrm{fM}^{-\mathrm{H}^{-}}$corresponding in a molecular formula of

'Dodicated to the memory of the late Professor Adhel Beckwith an oustanding Australian chemist. 
Table 1. NMR data $\left(\mathrm{D}_{2} \mathrm{O}\right)$ for fagraeoside

\begin{tabular}{|c|c|c|c|c|}
\hline Deritie: & $S_{2}^{A}$ & 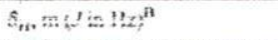 & coser & 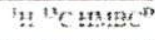 \\
\hline 1 & 99.8 & $5.53 . \mathrm{d}(1.7)$ & 9 & $3,5,8, \mathrm{Y}^{\prime}$ \\
\hline 2 & $19: 2$ & $7.23,312.2 ;$ & 5 & $\therefore 4,5,::$ \\
\hline 4 & 110.4 & - & - & - \\
\hline 5 & 26.6 & 3.10. $\mathrm{m}$ & $3.6 \mathrm{~b}$ & 3.6 .7 .9 \\
\hline 6 & 33.2 & $\begin{array}{l}\text { a } 2.22, \text { td }(12.8,4.0) \\
\text { b 1.58, ddd }(12.8,11.5,10.6)\end{array}$ & $\begin{array}{l}6 b, 7 \\
6 a, 5,7\end{array}$ & $\begin{array}{l}4^{E}, 5,7^{E}, 9 \\
4^{4}, 5,7^{E} \cdot 9\end{array}$ \\
\hline 7 & 66.2 & $5.24, \mathrm{dd}(10,6,4.0)$ & $6 a, 6 b$ & $5,6^{E}, 11^{\hat{E}}, 2^{\prime \hat{E}}$ \\
\hline 8 & 134,3 & 5.58 , ddd $\{17.1,10.1,9.9\}$ & $9.10 \mathrm{~s} .10 \mathrm{~b}$ & 1.5 .9 \\
\hline 9 & 448 & $2.80, \mathrm{~m}$ & 1,8 & $1.4,5,8,10$ \\
\hline 10 & 123.5 & $\begin{array}{l}\text { a } 5.37 \text {, dd }(17.1,1.4\} \\
\text { b } 5.30, \text { dt }\{: 0 . !, 1.4)\end{array}$ & $\begin{array}{l}8 \\
8\end{array}$ & $\begin{array}{l}8.9 \\
0\end{array}$ \\
\hline 11 & 168.3 & $-\quad 5$ & - & - \\
\hline $1^{\prime}$ & 100.9 & $4.83, \mathrm{~d}(8.0)$ & $z^{\prime}$ & $1,3^{\prime}, 5^{\prime}$ \\
\hline $2^{\prime}$ & 75.4 & $3.28 . \mathrm{dd}(9.4 .8 .0)$ & $1^{\prime}, 3^{\prime}$ & - \\
\hline $3^{\prime}$ & 78.2 & $3.50,2(0.4)$ & $2^{\prime}, 4^{\prime}$ & $2.4^{\prime}$ \\
\hline 4 & 72.4 & 3.40 , da $(9 \times, 9.4)$ & $3.5^{\prime}$ & $3^{\prime}, 5^{\prime}: 6^{\prime}$ \\
\hline $5^{\prime}$ & 79.1 & 3.51. ddd $(9.8 .6 .0 .2 .1)$ & 5. $6 \mathrm{~b}$ & $4^{\prime}$ \\
\hline $6^{\prime}$ & 63.5 & $\begin{array}{l}\text { a 3.92, dd }(12.4 .2 .1) \\
\text { b } 3.72 \text {, det }(12.4 .6 .0)\end{array}$ & $\begin{array}{l}6 \mathrm{~b} \\
6{ }^{\prime} 3.5^{t}\end{array}$ & $\begin{array}{l}4^{\prime} \\
5^{\prime}\end{array}$ \\
\hline $2^{\prime \prime}$ & 1755 & - & - & - \\
\hline $3^{\prime \prime}$ & 36.0 & $\begin{array}{l}\text { a } 2.83 \text {, dd }(166,7.3) \\
\text { b } 2.70 \text {, dd }(16.6,6.2)\end{array}$ & $\begin{array}{l}3 " b 4 " \\
3 " a, 4\end{array}$ & $\begin{array}{l}2^{\prime \prime} \cdot 4^{\prime \prime} \cdot 5^{\prime \prime} \\
2^{\prime \prime} \cdot 4^{\prime \prime}, 5^{\prime \prime}\end{array}$ \\
\hline $4^{\prime \prime}$ & 56.3 & $4.89, \mathrm{dd}(7,3.6 .2)$ & $3^{\prime \prime} a \cdot 3^{\prime \prime} b$ & $7,11,2^{\prime \prime}, 3^{\prime \prime}, 5^{\prime \prime}$ \\
\hline $5^{\prime \prime}$ & 178.9 & - & - & - \\
\hline
\end{tabular}

Dorra recorded at $100 \mathrm{MH}$, neferenced to TSP at $0.0 \mathrm{ppm}$

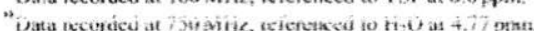

CData recorded at $500 \mathrm{MHz}$

${ }^{D}$ Data recordzd at $750 \mathrm{MHz}$ with ${ }^{\mathrm{C}} J_{67} 8 \mathrm{~Hz}$

Edditional conclations from data recorded at $750 \mathrm{MHz}:$ with $" j_{2 H} 4 \mathrm{HL}$

$\mathrm{C}_{20} \mathrm{H}_{20} \mathrm{~N}_{2} \mathrm{O}_{11}$. The ${ }^{13} \mathrm{C}$ NMR data (Table 1) were acquired in $\mathrm{D}_{2} \mathrm{O}$ and revealed 20 carbons, including three carbonyl signals at $\delta_{\mathrm{C}} 168.3,175.5$, and 178.9 . The $\mathrm{H}$ NMR data, also in $\mathrm{D}_{2} \mathrm{O}$, showed features twpical of a $\mathrm{B}$-glucose residue, including an anomeric proton at $\delta_{\mathrm{H}} 4.83\left(\mathrm{H}-\mathrm{H}^{\prime}\right)$ with the comesponding carbon at $\delta_{\mathrm{C}} 100.9$ by HSOC, a pair of multiplets (dd) at $\delta_{\mathrm{H}} 3.92 \mathrm{and}$ $\bar{\delta}_{\mathrm{H}} 3.72$ for $\mathrm{H}-6$, and resonances for four methine protons between $\delta_{11} 3.51$ and 3.28 . A fuil assignment of the glucose inoiety was provided from TOCSY. DQF-COSY, and nOe data.

Other structural features resembled a secoiridoid fragment. and included an alkene proton at $\delta_{13} 7.43(\mathrm{H}-3)$ with the corresponding carbons at $\delta_{\mathrm{C}} 151.2(\mathrm{C}-3)$ and $110.4(\mathrm{C}-4)$. an acetai proton at $\delta_{\mathrm{H}} 5.53(\mathrm{H}-1)$ correlated with a carbon at $\delta_{\mathrm{C}} 99.8$ by HSQC, and resonances for three vinylic protons at $\delta_{\mathrm{H}} 5.58$ ( $\mathrm{H}-8), 5.37$ ( $\mathrm{H}-10 \mathrm{a})$, and $5.30(\mathrm{H}-10 \mathrm{~b})$, with the correspording alkene carbons at $\delta_{\mathrm{C}} 134.3(\mathrm{C}-8)$ and $123.5(\mathrm{C}-10){ }^{2}$ A proton signal at $\delta_{\mathrm{H}} 5.24(\mathrm{HH}, \mathrm{dd}, J=10.6,4.0, \mathrm{H}-7)$ linked to a carbon at $\delta_{c} 66.2$ (d, C-7) supported either an $\alpha$-aminoacyl centre or an N.N aceial. The H-7 signal could be linked by DQFCOSY andior TOCSY correlations to signals at $\delta_{n} 2.22$

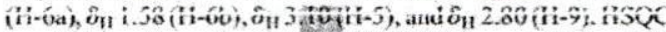
correlations then located $\mathrm{C}-5, \mathrm{C}-6, \mathrm{C}-7$, and $\mathrm{C}-9$, while geHMBC correlations (Fig. $\mathrm{Ja}$ ) from $\mathrm{H}-3$ and from $\mathrm{H}-7$ to an amide-like carbonyl at $\bar{\delta}_{\mathrm{C}} 1683$ identified the remaining 'secoiridoid' carbon C-11. The HMBC correlation between $\mathrm{H}-\mathrm{I}^{\prime}$ and $\mathrm{C}-\mathrm{I}$ confirmed the position of the glucose moiety. When the 'H NMR spectrum of fagracoside was run in DMSO$d_{\text {f }}$ a broad $\mathrm{NH}$ singlet at $\delta_{\mathrm{y}} 7.82$ was detected which gave HMBC correlations to $C-7$ and NOESY correlotions to $4 .-7$
The four remaining carbons were two carbonyls $\left(\delta_{c} \cdot 175.5\right.$, and 178.9), a methylene $\left(\delta_{\mathrm{C}} 36.0\right)$ and a methine $\left(\delta_{\mathrm{C}} 56.3\right)$. There were three unassigned proton signals: an $\alpha$-aminnacyl proton at $\delta_{u} 4.89 \mathrm{HH}$. dd, $\left.J=7.3 .6 .2 . \mathrm{H}-4^{\prime \prime}\right)$ linked to the carbon at $\delta_{c}-56.3$ by HSQC. and methylene protons at $\delta_{H} 2.83 \mathrm{iH}$ dd, $J=16.6 .7 .3, \mathrm{H}-3^{\prime \prime}$ ) and 2.70 (1H. dd, $J=16.6,6.2$ $\mathrm{H}-3 \mathrm{~b}$ ), linked to the signal at $\widehat{\zeta}_{\mathrm{C}} 36.0$ by $\mathrm{HSQC}$. HMBC correlations were from $\mathrm{H}-4^{\prime \prime}$ to $\mathrm{C}-3^{\prime \prime}$. to $\mathrm{C}-7$, and notably to the arnide $\mathrm{C}-11$ as well as to the two carbonyis at $\delta 175.5\left(\mathrm{C}-2^{\prime \prime}\right)$ and $178.9\left(\mathrm{C}-5^{\prime \prime}\right), \mathrm{H}-3^{\prime \prime}$ showed correlations to $\mathrm{C}-2^{\prime \prime}, \mathrm{C}-5^{\prime \prime}$, as well as to $\mathrm{C}-4^{\prime \prime}$, and $\mathrm{H}-7$ at $\delta_{11} 5.24$ showed correlations to $\mathrm{C}-2^{\prime \prime}$ and, as mentioned, to $\mathrm{C}-11$, while the $\mathrm{NiH}$ signal showed a correlation to $\mathrm{C}-3^{\prime \prime}$. These data fitted for a tetrahydropyrimic$4(3 \mathrm{H})$-one ring constructed biosynthetically from the condensa-

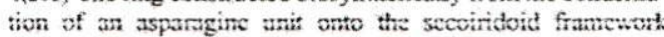
(Fig. 2). An alternative tetrahydropyrimid- $4(3 H)$-one structure with the free carboayl group at $\mathrm{C}-3^{\prime \prime}$ instead of at $\mathrm{C}-4^{\prime \prime}$ was both inconsistem with the ${ }^{1} \mathrm{H}$ and ${ }^{13} \mathrm{C}$ chemical shifts of $\mathrm{C}-3^{\prime \prime}$ and $\mathrm{C}-4^{\prime \prime}$ and would be biosynthetically-unprecedented. The tetrabydropyrimid-4(3H)-one jadomycin $\mathrm{N}$ with $\delta_{c} 66.95$ for the $N, N$

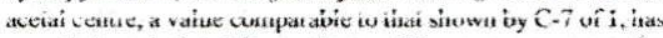
recentiy been isolated from cultures of Sireptomvces venezuelate ISP5230 grown on I-asparagine as sole nitrogen source. ${ }^{[10\}}$

The relative configuration was deduced from NOESY data (Fig. Ib) which showed correlations from $\mathrm{H}-5$ to $\mathrm{H}-7$ and to $\mathrm{H}-9$, and between $\mathrm{H}-7$ and the diastereotopic proton at $\delta_{\mathrm{k}} 2.83$ $\left(\mathrm{H}-3^{\prime \prime} \mathrm{a}\right)$. Modelling of fagraeoside was undertaken using $\mathrm{Chem}$ Bio 3D uhra 12.0 (Cambridge), using MM2 software for energy minimizotion to on RMS gradient of 0100 and meveled a

${ }^{2}$ Standard secoiridoid numbering used throughout. 
(a)

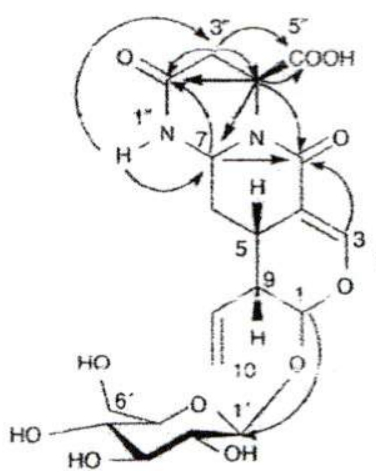

(b)

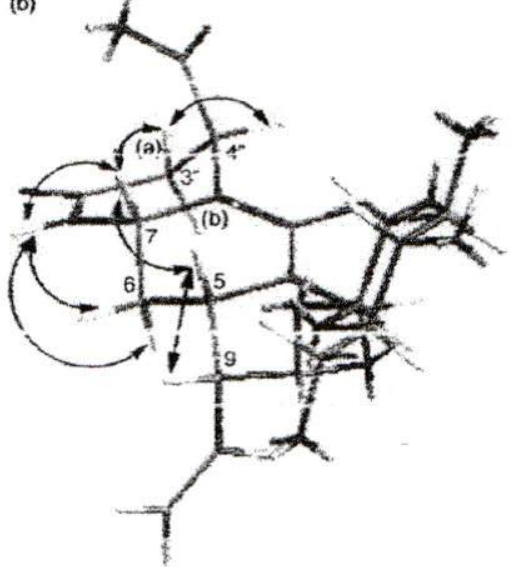

Fig. 1. Structure of tagracoside ( $)$ ) showing (a) imponant HMBC carretations obserred in $d_{\phi}$-DMSO.

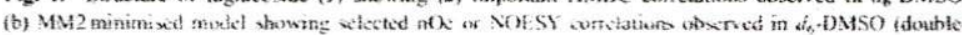
beaded arrows.

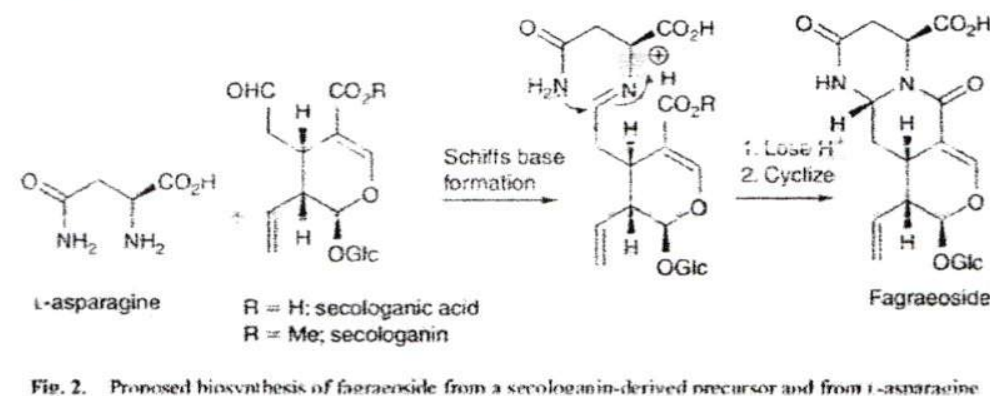

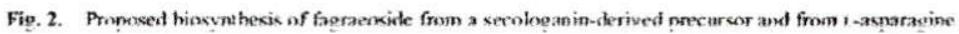

flattened chair for the tetrahydropyrimidirone ring. In the ' $\mathrm{H}$ NMR in $\mathrm{D}_{2} \mathrm{O}, \mathrm{H}-4^{\prime \prime}$ appeared as a doublet of doublets with $J$ values of $7.3 \mathrm{~Hz}$ to $\mathrm{H}-3^{\prime \prime} \mathrm{a}$ and of $6.2 \mathrm{~Hz}$ to $\mathrm{H}-3^{\prime \prime} \mathrm{b}$, matching the observed ditedral angles in 1 between $\mathrm{H}-4^{\prime \prime}$ and $\mathrm{H}-3^{\prime \prime} \mathrm{a}\left(56.7^{\circ}\right)$ and $\mathrm{H}-3^{\prime \prime} \mathrm{b}\left(61.8^{\circ}\right)$. When the $\mathrm{C}-4^{\prime \prime}$ epimer was modeled. the measured dihedral angles were respectively $64.6^{\circ}$ and $175.9^{\circ}$ which would have led to one large $J$ value for the $\mathrm{H}-4^{\prime \prime}$ signal. Although such data must be used with care, the absence of a NOFSY correlation between $\mathrm{H}-7$ and $\mathrm{H}-4$ " was also consistent

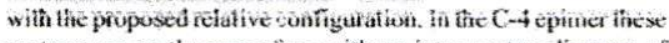
protons are on the same face with an inter proton distance of $2.6 \AA$. whereas in 1 , they are on the opposite face, and thus $3.9 \AA$ apart.

Another melabolite isolated from $F$. racemosa was $(-)-$ secologanoside $(2)^{[9]}$ which was easily recognised by comparison of its Nivik data with the itterature. The presence of a D-glucose moiety in 1 and in 2 was confirmed by acid bydro!yis, derivatization with TFAA and emntioselextive as chromatography. ${ }^{[1]}$ The absolute configuration shown for 1 is further supponted by its co-isolation with secologanoside, and by the proposed role of secologanin in the biosynthetic pathway of 1 . Consequently, L-asparagine is implicated in the biosynthesis of 1 .

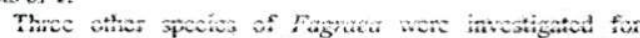
their chemistry. Stem bark from the species $F$. biumei yielded first, from the methanolic fraction, di-O-methylcrenatin $(3)^{[12]}$ potahosicic $B(4)^{i 12 i}$ the iridoid glucoside adoxosidic acid

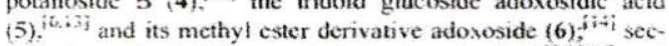
ond. from the DCM extract, $(+)$-pinoresinol $(7)^{[5,15.16]}$ and salicifoliol $(8)^{[t 6]}$ Di-O-methylcrenatin (3), adoxosidfic acid (5). and adoxoside (6) have all been previously reponed from F. blamei ${ }^{161}$ The iridoid glucoside loganic acid $(9)^{[17]}$ and the secoiridoid glucoside sweroside $(10)^{[1 \times]}$ were isolated from $F$. auriculata together with potalioside B (4). An extract from $F$. ceilanica yielded two hydroxyflavanol $\mathrm{C}$-glycosides whose

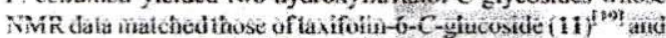
aromadendrin-6-C-glucoside $(12)^{[20]}$ together with secologanoside (2) and loganic acid (9) (Fig. 3).

In view of the traditional usage of Fagraea bark as an antiinflammatory and antipyretic agent, compound $\mathbf{i}$ was sereened for cytotoxicity and anti-inflammatory activity. [21] Although 1 innibited the producrion of $\mathrm{FGt}_{2}$ in 373 munne nibrobiasts ili se $5.1 \mu \mathrm{M}$ ), an atypical dose response curve was obtained (Fig. 4).

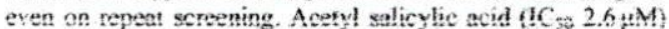
was used as a positive control. The observed anti-inflammatory activity did not appear to be a cytotoxic response since the compound lacked cytotoxicity to the $3 \mathrm{~T} 3$ cells, and also to a P388 murine leukaemia cell line, when compared with chlorambucil as a reference compound. Additional testing is required

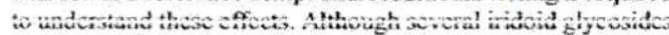
show useful anti-inflammatory activity, there are few such reports for seco-iridoids. ${ }^{122,23 \mid}$ Compounds $1,2,4,7,9.11$. 


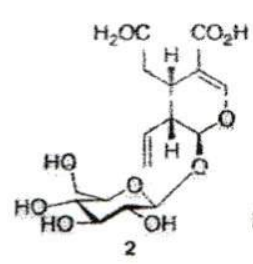<smiles>COc1cc(CO)cc(OCC(O)C(O)O)c1O</smiles>

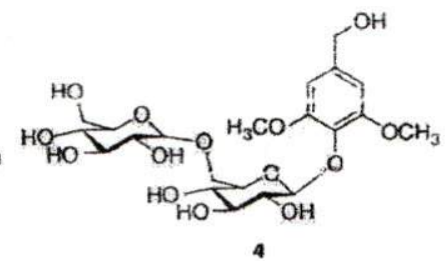

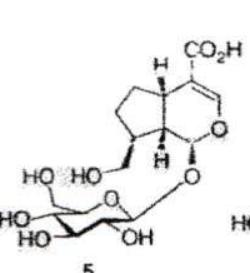

5

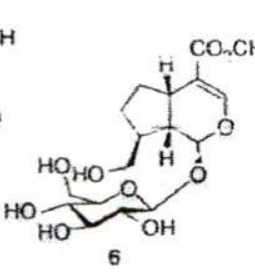

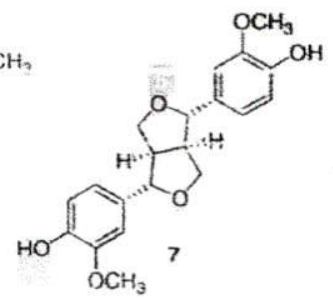<smiles>COc1ccc(C23COCC2C(=O)OC3)cc1O</smiles>

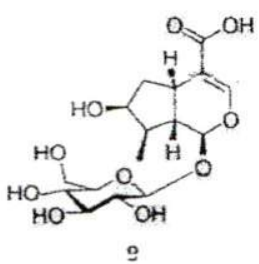

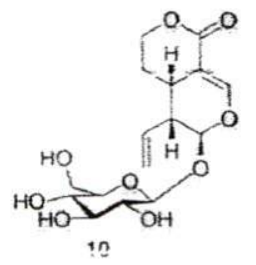<smiles>O=C1c2c(cc(O)c(O)c2O)O[C@H](c2ccc(O)cc2)C1O</smiles>

$11 \mathrm{R}=\mathrm{OH}$

$12 R=H$

Fig. 3. Secoiridoid glycoside, inidioid glycoside, and hignan metabolites from Fagraed spp

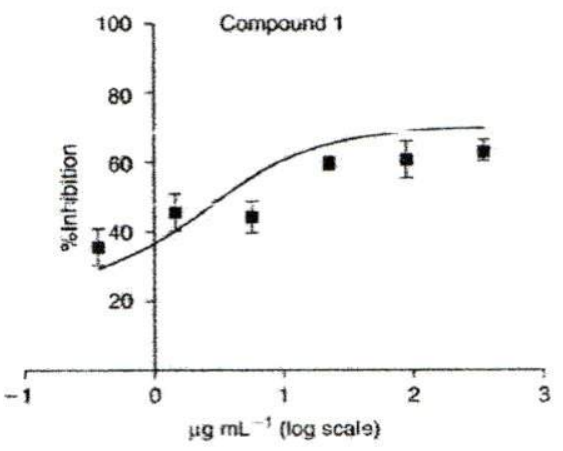

Fig. 4. Anti-inflammatory activity of fagracesside against $3 \mathrm{~T} 3$ murine fibroblast cells.

and 12 were also screened for anti-acetylcholinesterase activify in an assay using Ellman's reagent. 5,5 -dithiobis- 2 -nitrobenzoic acid) (DINB), ${ }^{\text {F*3 }}$ with the data quantitied by detection at $415 \mathrm{~nm}$ using a microplate reader. ${ }^{[24,25]}$ The inhibition observed for all eight metabolites at $100 \mu \mathrm{gmL}$ was similar to the inhibition found for galanthamine $\mathrm{HBr}$ salt at $0.184 \mu \mathrm{gmL} \mathrm{L}^{-1}$. which indicated that the meiabolites are relatively weak inhibitors of acetylcholinesterase.

\section{Conclusion}

One of the largest group of plant alkaloids are the indote alkaloids formed from the condensation of secologanin with the aromatic amino acid tryptophan. This paper has described the structure and stereochemistry of a novel alkaloid that may be derived in Nature from the condensation of secologanin with the amino acid $t$-asparagine. There are remarkably few reports of terpene afkaloids in the literature in which the amino acid component is non-aromatic. Machida et al. $(2002)^{[26]}$ have descrobed L-pheny fataninosecologaniti, presumabily formed oy enzymatic reduction of the Schiffs base product of secologanin and L-phenylalanine, from Lonicera japonica Thunb. Our investigations on the secondary metabolites of the genus Fagraea have revealed the presence of iridoid and secoiridoid glycosides in all fous species studied, and when considered together with an cartier titerature report ${ }^{i 0}$ suggest that such compounds may be chemotaxonomic markers for the genus. 
Experimental

General

Reverse phase HPLC was conducted on an Agilent 1100 series instrument with variable wavelength UV detector set at 240 or at

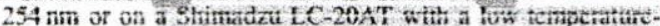
evaporative light seattering detector (EL.S.D.-LT) fitted with a semi-preparative Waters ${ }^{5}$ HLC column ( $\mu$ Bondapak $C_{78}$ $7.8 \times 300 \mathrm{~mm}$ ) or a Phenomenex ${ }^{2}$ column (Gemini 5 mieron $10 \times 250 \mathrm{~mm}$ ). Positive or negative ion electrospray mass spectra (LRESMS) were determined using a Bruker Esquire

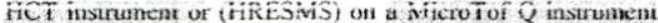
each with a standard ESI source. Optical rotation $[\alpha]_{D}$ meastrements wre taker on a Perkin-Fumer $241 \mathrm{MC}$ or a AASCO P- 1010 polarimeter. The ${ }^{1} \mathrm{H}$ and ${ }^{13} \mathrm{CNMR}$ data were measured on Bruker Avance 400,500 , or $750 \mathrm{MH} / \mathrm{z}$ spectrometers at $298 \mathrm{~K}$ Normal phase and reverse phase thin-layer chromatography were performed on Merck Art 5554 and 5559 atuminium backed plates precoeted with silica gel Merk Kieselgel $(6)$

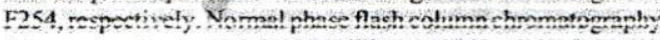
was undertaken on Scharlau silica gel $60,0.04-0.06 \mathrm{~mm}$ (230-400 mesh ASTM), while reverse phase flash column chromatography was carried out on silica gel prepared using the method developed by Evans et al. ${ }^{\{273}$ Acetyleholinesterase inhibition assay measurements were performed using a Bio-Rad Model 550 microplate reader at $415 \mathrm{~nm}$.

\section{Colfection, tatuction, and tolation}

Stem bark of F. blumei G.Don (SC0106) was collected in Malang. East Leva, Imtonesin on 16 November 2006. Stem bark of $F$. ceilanica Thunb (SC0206) and $F$. racemosa JACK ex WALL (voucher sample SCO306) was collected on 16 November 2006 from Purwodadi Botanic Garden. East-Java, Indonesia. A methanolic extract of the stem bark of $F$. auriculate Jack, Mall isample collected 26 February 2001: voucher

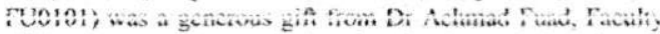
of Pharmacy. Arrangga University, Surabaya. Indonesia. Al plants were identified by staft of Purwodad: Botanic Farden. East Java, Indonesia; voucher samples are stored in the Facuity of Pharmacy, Airlangga University. Plant materials were chopped and air-diried at room temperature for 5 days and then powdered using a biender.

Powdered stem bark of $F$, racenosa $(530 \mathrm{~g})$ was macerated with hexanes $(3 \times 24 \mathrm{~h}$, then with $\mathrm{DCM}$. and finaliv by $\mathrm{MeOH}$ The methanolic extract $(18 \mathrm{~g})$ was fractionated by vacuum liquid chromatography, with a gradient of $\mathrm{CHCl}_{3}, \mathrm{MeOH}$, and $\mathrm{H}_{2} \mathrm{O}$ in increasing polarity, and afforded 9 tractions. Fraction 8 , namely FRM8, was then partitioned by NP flash chromatography, using EtOAc, $\mathrm{MeOH}$, and $\mathrm{H}_{2} \mathrm{O}$ in order of increasing polarity. The first three fractions, namely FRM 801,802 , and 803 eluting in $\mathrm{E} 1 \mathrm{OAC} / \mathrm{MeOH}$ (9:1), EtOACMeOH/H $\mathrm{O}$ (9:1:1), and $\mathrm{EtOAC}$ $\mathrm{MeOH} \mathrm{H}_{2} \mathrm{O}(\$: 2: 1)$, respectively containcd secologaneside (2) (134.6 mg). The fourth fraction. FRM804, was subjected to flash chromatography on $\mathrm{SiO}$, using a solvent mixiure of EtOAC

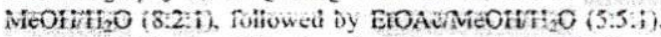
and yielded 9 fractions. Fractions 7 and 8 , namely FRM 8047 and FRM8048, were then subjected to RP-HPLC using a gradient of $0-50 \% \mathrm{MeOH}$ in $\mathrm{H}_{2} \mathrm{O}$ for $30 \mathrm{~min}$, with UV detection at $240 \mathrm{~mm}$. and flowrate $1.5 \mathrm{~mL} \mathrm{~min}{ }^{-1}$. The component eluting at $20.9 \mathrm{~min}$ was fagraeoside (1) (3.5 mg).

powdered stem bark of $\bar{F}$. flumet ( $\mathrm{i} \mathrm{kg}$ ) was macerated in hexanes, followed by DCM and $\mathrm{MeOH}$ using the same procedure as $F$, racemesa. A portion of the MeOH extract $(382 \mathrm{mg})$ was chromatographed on RP-silica gel using a solvent gradient from 0 to tonos Man!y in H.O. A frection eluting in $0.2 \mathrm{n \%} \times \mathrm{MeOH}$ $\mathrm{H}_{2} \mathrm{O}$ contained di-O-methylcrenatin ( 3 ) $(3.7 \mathrm{mg}$ ), potalioside $\mathrm{B}$ (4) (1.4 $\mathrm{ng}$ ), and a mixture of adoxosidic acid (5) (3.4 $\mathrm{mg}$ ) and adoxoside (6), which were further purified by RP-HPLC $(0-50 \%$ $\mathrm{MeOH}$ in $\mathrm{H}_{2} \mathrm{O}$ for $60 \mathrm{~min}$, detection at $254 \mathrm{~nm}$ ). The DCM extract $(11.8 \mathrm{~g})$ was chromatographed on kieselgel $60 \mathrm{H}$ using hexanes, DCM, and $\mathrm{MeOH}$ in order of increasing polarity, followed by column chromatography on Diaion HP-20, using a solvent gradient $120 \% \mathrm{H}, \mathrm{O}$ in $\mathrm{MeOH}$ to $100 \% \mathrm{MeOH}$ ) yielding 5 fractions. Fraction 1 was then subjected to RP-HPLC $150 \%$ $\mathrm{MeOH}$ in $\mathrm{H}_{2} \mathrm{O}$ for $50 \mathrm{~min}$, detection at $254 \mathrm{~nm}$ ) to afford $(+1$-pinore sinoi (7) $(3.8 \mathrm{mg})$ and saicitoitioi $(\overline{8})(1.2 \mathrm{mg})$

Extraction of powdered stem bark of $F$. auriculata was undertaken using the same procedure employed for $F$. racenresc and $F$ bhomei. The $\mathrm{MeOH}$ extract $(368 \mathrm{mg}$ ) was subjected to RP-flash column chromatography with a solvent gradient from 0 to $100 \% \mathrm{MeOH}$ in $\mathrm{H}_{2} \mathrm{O}_{4}$ and yielded 19 fractions. Fraction 4 was further puntied by RP-HPLC with a gradient of 20 to $30 \%$ $\mathrm{MeOH}$ in water over $60 \mathrm{~min}$ to afford loganic acid $(9)(1.16 \mathrm{mg})$

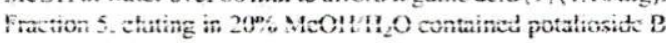
(4) $\left(8.79 \mathrm{mg}\right.$, while fraction $6\left(50 \% \mathrm{MeOH} \mathrm{H}_{2} \mathrm{O}\right)$ afforded sweroside (10) $(33.9 \mathrm{mg}$ ).

Srem bark of $F$ ccilanica ( $488 \mathrm{~g}$ ) was extracted in the same way. A portion of the methanolic extract $(3.9 \mathrm{~g})$ was partitioned by $R$ P-llash chromatography using a solvent gradient from

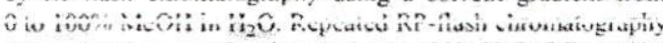
was undertakem on a fraction eluting in $100 \% \% \mathrm{H}, \mathrm{O}$. followed by senu prenarative RP.TLC with MeOH/H,O (3/7) to obtain five fractions. Fractions 2 and 3 were further purified by RP-HPLC (15-50\% MeOH in $\mathrm{H}_{2} \mathrm{O}$ containing $0.1 \%$ TFA for $30 \mathrm{~min}$, detection at $254 \mathrm{~nm}$ ) to yive taxifotin-6-C-glucoside (11) $(22.9 \mathrm{mg})$ from fraction 2 , and aromadendrin-6- $C$-glucoside (12) (14.1 mg), loganic acid (9) (5.8 $\mathrm{mg}$ ), and secologanoside (2) (1) $1 \mathrm{~mm}$ ) from fraction ?

Fagraeoside (1). Palc yellow amorphous solid $(3.5 \mathrm{mg}$ ): $[x]_{\mathrm{D}}^{23}-38.6$ (c $\left.0.57, \mathrm{H}_{2} \mathrm{O}\right): \mathrm{UV}\left(\mathrm{H}_{2} \mathrm{O}\right) i_{\max }(\log 5) 241$ (3.53) nm: ' $H$ and 'C NMR (D,O. 750 and $100 \mathrm{MHz}$ ), see Table 1: 'HNMR (DMSO- $\left.d_{6}, 750 \mathrm{MHz}\right) \delta 7.82(\mathrm{HH}, \mathrm{brs}, \mathrm{NH}$ ). $7.28(1 \mathrm{H}$, d, $J=2.4, \mathrm{H}-3), 5.47$ ( $\mathrm{H}$, ddd, $J=17.2,10.3,10.0$ H-8), $5.36 \mathrm{fH}, \mathrm{d}, J=1.7, \mathrm{H}-1), 5.30(1 \mathrm{H}, \mathrm{dd}, J=17.1 .2 .0$ H-10a), $5.22(1 \mathrm{H}$, dd. $J=10.3,2.0, \mathrm{H}-10 \mathrm{~b}), 5.19(1 \mathrm{H}, \mathrm{dd}$ $J=11.6,3.0 . \mathrm{H}-7$ ). 4.90 (HH. br d, $\left.J=6.8, H-4^{\prime \prime}\right), 4.51$ (HH. d. $\left.J=8.0, \mathrm{H}-\mathrm{l}^{\prime}\right), 3.68\left(\mathrm{HH}, \mathrm{m}, \mathrm{H}-6^{\prime} \mathrm{a}\right), 3.42\left(\mathrm{HH}, \mathrm{m}, \mathrm{H}-6^{\prime} \mathrm{b}\right), 3.14(2 \mathrm{H}$ m, $\mathrm{H}-3^{\prime}$ overlapping with $\left.\mathrm{H}-5^{\prime}\right), 53\left(\mathrm{IH}, \mathrm{m}, \mathrm{H}-4^{\prime}\right), 2.98(\mathrm{HH}, \mathrm{m}$.

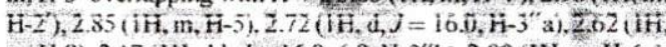
$\mathrm{m}, \mathrm{H}-9), 2.17$ (1H, dd, $\left.J=16.0,6.8, \mathrm{H}-3^{\prime \prime} \mathrm{b}\right), 2.00(1 \mathrm{H}, \mathrm{m}, \mathrm{H}-6 \mathrm{a})$ $1.20(1 \mathrm{H}, \mathrm{m}, \mathrm{H}-6 \mathrm{~b}) \mathrm{H}^{13} \mathrm{C}$ NMR (DMSO-d $6.750 \mathrm{MHz}$, partial data from HMBC) $\delta 161.8(\mathrm{C}-11), 146.6(\mathrm{C}-3), 132.9(\mathrm{C}-8), 119.8(\mathrm{C}$ $10), 107.0(\mathrm{C}-4), 98.6\left(\mathrm{C}-3^{\prime}\right), 95.4(\mathrm{C}-1), 77.1\left(\mathrm{C}-5^{\prime}\right), 76.7(\mathrm{C}-3)$. $72.8\left(\mathrm{C}-2^{2}\right), 69.8\left(\mathrm{C}-4^{\prime}\right), 62.6(\mathrm{C}-7), 61.0\left(\mathrm{C}-6^{\prime}\right), 50.6\left(\mathrm{C}-4^{\prime \prime}\right), 42.0$ $(\mathrm{C}-4), 34.4\left(\mathrm{C}-3^{\circ}\right), 32.9(\mathrm{C}-6), 23.8(\mathrm{C}-5)$; HRESIMS catcd. tor $\mathrm{C}_{20} \mathrm{H}_{26} \mathrm{~N}_{2} \mathrm{O}_{14}$. 469.1458. Found: $m / z 469.1468[\mathrm{M}-\mathrm{H}]$

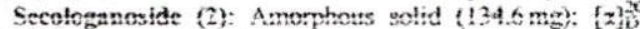
$\left.-98.37 \mathrm{c} 0.12 . \mathrm{H}_{2} \mathrm{O}\right)$; UV $\left(\mathrm{H}_{2} \mathrm{O}\right) i_{\max }(\log z) 24 i(3.53) \mathrm{nm}$ the ${ }^{1} \mathrm{H}$ and ${ }^{13} \mathrm{C}$ NMR data were comparable with published values: ${ }^{\mid 0 /}$ LRESIMS $m i z 413.2[\mathrm{M}+\mathrm{Na}]^{+}$.

\section{Determination of Glucose Absolute Configuration}

the giucose moieties were characterised according to the method of Hayes et al. ${ }^{\text {fit }}$ A sample of either fagraeoside 
$(0.74 \mathrm{mg})$ or secologanoside $(5.63 \mathrm{mg})$ was heated for $2 \mathrm{~h}$ a $100{ }^{\circ} \mathrm{C}$ with $10 \% \mathrm{HCl}$ in $\mathrm{McOH}(0.5 \mathrm{~mL})$. After cooling, the solution wes concert-ered under $\mathrm{N}_{2}$, than portitioned between water and $\mathrm{CHCl}_{3}(0.5 \mathrm{~mL})$ and the aqueous layer concentrated under $\mathrm{N}_{2}$. The residue was dissolved in a nuxture of trifluoroacetic anhydride (TFAA) DCM $(1 / 1,0.2 \mathrm{~mL})$ and then analysed by enantioselective chromatography (Chirasil-L-Val capillary column $(25 \mathrm{~m} \times 0.32 \mathrm{~mm} \times 0.2 \mathrm{~mm})$, FID detection, carrier gas: heliun, injector: $200^{\circ} \mathrm{C}$, colum fiow $1.32 \mathrm{~mL} \mathrm{~min}^{-1}$, split ratio: $56 \%$, and pressure $40 \mathrm{kPa}$. Temperature program initial temperature $50^{\circ} \mathrm{C}$ for $6 \mathrm{~min}$. raised at $4^{\circ} \mathrm{C} \mathrm{min}^{-1}$ to a final temperature of $160^{\circ} \mathrm{C}$ for $5 \mathrm{~min}$ ). For comparison, standards were prepared from D- and L-glucose. Under these conditions, retention times were $\mathcal{L}$-Gic $(20.22$ and $2 y .88 \mathrm{~min})$ D-Gic (20.31 and $30.07 \mathrm{~min}$ ). For glycoside 1, peaks were observed at 26.30 and $30.06 \mathrm{~min}$, and for glycoside 2, peaks were observed at 26.26 and $30.02 \mathrm{~min}$ corresponding to D-glucose. Co-injection of either glucose pentatrifluoroacetate product with the D-glucose reference standard gave in each case a single peak.

Evaiuation of Antr-intiammatory Activity and Cytotoxicity The prostaglandin $\mathrm{E}_{\text {z }}$ assay was undertaken using Swiss albino mouse embryo fibroblast cells 3T3 (American Type Culture Collection (ATCC), Manassas, VA) and a PCE, enzyme immuno-assay kit (Prostaglandin $\mathrm{E}_{2}$ ELA kil-monoclonal, Cavman Chemical Co.. Ann Arbor. Ml. catalogue no. 5141010) using acetyl salicylic acid as a positive control. Cytotoxicity in $3 \mathrm{~T} 3$ murine fibroblasts, and in P388D1 murine lymphoblasts (AiCL) was assayed using an AiPlite kit (P̈erkinEimer. Waltham, MAs with chlorambucit as a reference compound. Details of both assays have recently been published $\{2 !\}$

Evaluation of Acetylcholinesterase Inhibition

Compount rese disted in MeOL to a coccentrotion of i mg mL ${ }^{-1}$. Galantnamine $\mathrm{HBr}$ salt was diluted in $\mathrm{MeOH}$ to a concentretion of $100 \mu \mathrm{M}$. A solution of acetylthiochohine iodide in Millipere water $(15 \mathrm{mM}, 30 \mu \mathrm{L})$ was placed in each well of a 96-well plate. Then in sequence, $5.5^{\prime}$-dithiobis-(2-nitrobenzoic acid in Millipore water $(3 \mathrm{mM}, 150 \mu \mathrm{L})$ and a buffer solution of bovine serum albumin $(0.1 \%)$ made up in TRIS-HCl buffer $(50 \mathrm{mM}, \mathrm{pH} 8.0,60 \mu \mathrm{L}$ ) were added. followed by the compound under assav $(30 \mathrm{uL})$ or by galanthamine $\mathrm{HBr}$ salt $(30 \mu \mathrm{LL}$. A blank well contained methanol $(30 \mu \mathrm{L})$ instead of the compound under assay. The plate was shaken carefully to homogenize the mixture and the absorbance of individual wells at $413 \mathrm{~nm}$ was measured 10 times at intervals of $30 \mathrm{~s}$. Acetylcholinesterase solution $\left(0.22 \mathrm{U} \mathrm{mL}^{-1}, 30 \mu \mathrm{L}\right)$ was then added, the individus piates shaken and the absorbance measurements repeated a further 10 times. The experiments were done in quadruplicate in three independent experiments.

\section{Accessory Publication}

The Accessory: Publication contains copies of representative NMR spectra, including the ${ }^{1} \mathrm{H}$ and ${ }^{13} \mathrm{C}$ spectra of fagraeoside (1) in $\mathrm{D}_{2} \mathrm{O}$, together with HMBC. NOESY, and RGESY data, and the ${ }^{1} \mathrm{H}$ and ${ }^{33} \mathrm{C}$ spectra of secologanoside $(2)$ in $\mathrm{D}_{2} \mathrm{O}$. Also included are characterisation details and spectroseopic data of rosunoumds 2-12 The Acreserry Puhtiration ic available on the Journal's website.

\section{Acknowledgements}

The authers thank AusAlD for the award of an Australian Development

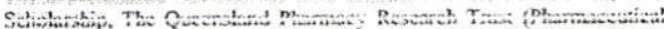
Society of Australia, Queensland branch) for financial suppon for the acetylcholinesterase inhibition assay, and Dr Achnod Fuad (Faculty of Pharmacy, Airlangea University, Surabaya, Indonesia) for the $F$, aurictiato samp. We thank Dr Paricia Hayes for assisance with the enantioselective GC characterisation of D-gluecese. Mr Graham McFartane and Dr Tri Le assisted with MS and NMR measurements respectively

\section{References}

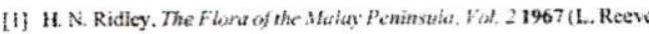
\& Co, Lid: L London.

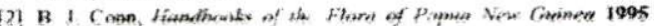
(Melbourne University Press: Meibourne).

[3] C. Wian, Medicinal Plants of the Asia-Pacific: Drugs for the Yinture 2006 (World Scientific Publishing Ltd.: Singapore).

[4] M. A. Oasim. S. K. Roy. M. Karnil. M. Hyas, Phyzochemistry 1987.26, 2871. do: 10.1016S0031-9422100)83614-6

[5] E. Otuyama, K. Stcautura ive. Yanazaki, Chem. Phurm. Bull. (Tohoo) 1995, 43, 2200.

[6] M. Cusndet, K. Hostertmann. O. Potterat, W. Dyatmiko, Helv. Chim

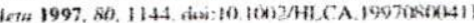

17) A. S. C. Wan. Y. L. Chow, 1. Pharm. Pharnaced. 1964, J6. 484.

[s] S. Hayashi, H. Kameohas S, Hashimote. K burthawa. $T$ Arai. 1. Exsent Oit Res. 1995, 7. 505.

(9) 1. Calis. O. Sticher. Phytecharnistry 1984, 23. 2539. doci0.1016/ $50031-9422(000) 8+094-7$

[10] C \& Boriscow, C I Graham, R. T Syvitski. T. R Reid, J. Blay,

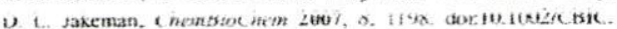
$20 \times 7(x) 204$

III) P. Y. Hayes. R. Letriann, K. Penman. W. Kitchim, 3. 1. De Voss, Phtechemistr 2009, 70, 105, doi:10 10163. PHYTOCHEM 2008. 10019

[12] X. C. Li, H. N. ElSohly, L. A. Wilker. A. M. Clark, Pianta Med. 2005. 71. 977. doi 191.1655/S-2005-671233

[13] D. R. Gandner, J. Narum, D. Zook. F. R. Stermitz, f. Nat. Prod. 1987. 50. 485. doi: 10. 1021/NP50051A02-

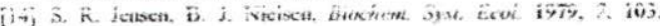

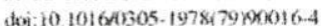

[15] N. R. Gity. F. R. Stermiz. Phytochemistry 2009. 54, 897 . doi:10.1016 S0031-9422100)00101-1

(16) A G. Gonzalez, R. Estévez-Reyes. C. Mato. J. Nat. Prod. 1989, 52 1139. doi: Ho. 102 LNP5006iAn37

[t7] I. Calis, M. F. Lahfouth O. Sticher. Helv, Chim. Acia 1984, 67, 160. doi: $10.1002 / 41 . C A .19840670119$

[18] Y. Zhou, Y. T. Di, S. Gesang, S. L. Pene, L. S. Ding, Hetv. Chim. Acte

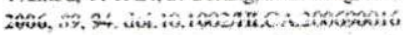

$[19]$ J. T. Mbafor, Z. T Formum. R. Promsattha, D. R. Samson, M. S Tempesta, S. Nut. Prod 1989. 32, 417. doi:10.1021/NP50062A039

[20] Y. Hayashi, S. Ohara, T. Fakahashi, Mokuzui Gahkaishi 1987, 33,5H].

[21] H. Wohlmuth, M. A. Deseo, D. J. Brushet, D. R. Thompson, G. MacFarkane, L. M. Stevenson, D. N. Leach. 1. Nat. Prod 2018, 73. 743, doi:10 1021/NP960688R

[22j R. Tundis, M. R. Loizm. F Menictini, G. A. Starti, F. Menichini, Mint Rev . Hed. Chem. 2008, \&, 399, dor: $10.2174 / 138955708783955926$

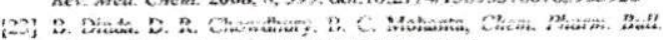
(Tokyo) 2009, 57, 765. dow:10.1248CPB 57.765

[24] G. L Ellnan K. D. Ciurthcy, V. Andres, R. M. Featherstone. Bischem Pharmuteol 1961, ?. 88. deri:10.101670006-2952(61) $90145-9$

[25] 1. K. Rhee, M. van de Meent. K. Ingkaninan. R. Verpoorte.

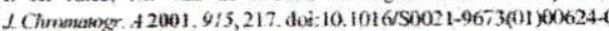

[26] K. Machida, H. Sasaki, T. Litima, M. Kikuchi. Chem. Pharm. Bull (Tohyo) 2002, 50, 1041. doi: 10.1248/CP8.50, 1041

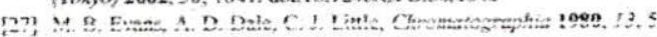
doi: 10 . $1007 / \mathrm{BP} 0230270$ 
Phytochemical Study of Fagraea spp. Uncovers a New Terpene Alkaloid with Anti-Inflammatory Properties

\section{ORIGINALITY REPORT}

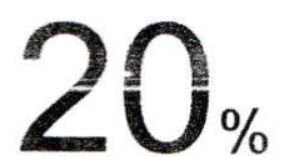

SIMILARITY INDEX

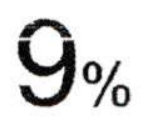

INTERNET SOURCES

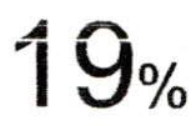

PUBLICATIONS
$0 \%$

STUDENT PAPERS

PRIMARY SOURCES

1. www.siidesnare.net

Internet Source

2. Patricia 'Ý. Hayes, Reg Lehmann, Kerry

Penman, William Kitching, James J. De Voss.

"Steroidal saponins from the roots of Trillium

erectum (Beth root)", Phytochemistry, 2009

Publication

3. Kitajima, M.. "Camptothecin-related alkaloids from hairy roots of Ophiorrhiza pumila",

Tetrahedron, 20021104

Publication

Suciati, James A. Fraser, Lynette K. Lambert, Gregory K. Pierens, Paul V. Bernhardt, Mary J.

Garson. " Secondary Metabolites of the

Sponge-Derived Fungus ", Journal of Natural

Products, 2013

Publication 
6. Rudiyansyah, , and Mary J. Garson. "Secondary

Metabolites from the Wood Bark of Durio

zibethinus and Durio kutejensis", Journal of

Natural Products, 2006.

Publication

7

Patricia Y. Hayes. "Complete1H and13C

assignments of the four major saponins

fromDioscorea villosa (wild yam)", Magnetic

Resonance in Chemistry, 11/2007

Publication

8 diyhpl.us

9. Ping-Chung Kú, Hisin-Y̌i Hiung, Ćni-Vivei Nvian,

Tsong-Long Hwang et al. " Chemical

Constituents and Anti-inflammatory Principles

from the Fruits of ", Journai of N Naturai

Products, 2017

Publication

iviuriei Cuendet. "iridoid Giucosides with Free

Radical Scavenging Properties fromFagraea

blumei", Helvetica Chimica Acta, 06/30/1997

publication

Henrik Franzyk. "SYNTHESIS OF NOVEL

HYDROXYMETHYL SUBSTITUTED

ANALOGUES RELATED TO CARBOVIR AND

NEPLANOCIN A", Nucleosides Nucleotides \&

Nucleic Acids, 2002 
12 Adib Charafeddine. "First Synthesis of 2'-

Deoxyfluoropuromycin Analogues:

Experimental Insight into the Mechanism of the

Staudinger Reaction", Chemistry - A European

Journal, 06/25/2007

Publication

13

Waffo-Teguo, P.. "Acetylated glucuronide

triterpene bidesmosidic saponins from

Symplocos glomeratai", Phytochemistry,

200403

Publication

14 Ch. Turghun, ini. Bakri, G. A. Żou, Ḱn. ỉ.

Bobakulov, H. A. Aisa. "Phenolic Compounds from Leaves of Nitraria sibirica", Chemistry of

Naturai Compounds, 2018

Publication

15 Essam Abdel-Sattar. "Saponin Glycosides from

Osteospermum vaillantii", Pharmaceutical

Biology (Formerly International Journal of

Pharmacognosy), 12/1/2001

Publication

Lawrence Onyango Arot Manguro. "Phenolics

of Moringa oleifera leaves", Natural Product

$<1 \%$

Research, 01/2007

Publication

Hai-Feng Chen. "Novel furostanol saponins 
17. from the bulbs of Allium macrostemon $B$. and their bioactivity on [Ca 2+] i increase induced $<1 \%$ by $\mathrm{KCl}$ ", Journal of Asian Natural Products

Research, 1/1/2006

Publication

Nicholas J. Matovic. "The Truth about False

Unicorn (Chamaelirium luteum): Tota!

Synthesis of 23R,24S-Chiograsterol B Defines

the Structure and Stereochemistry of the Major

Saponins from this Medicinal Herb", Chemistry

- A European Journal, $06 / 27 / 2011$

Publication

Ken W'V.L. Ýong, Angeia Â. Salim, iviary j.

Garson. "New oxygenated diterpenes from an

Australian nudibranch of the genus

Chromodoris", Tetranedron, 2008

Puílication

20. AKDEMIR, Zeliha Ş., TATLI, İ. İrem, BEDIR,

Erdal and KHAN, Ikhlas A.. "Iridoid and

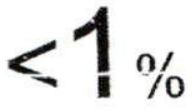

phenylethanoid glycosides from Verbascum

lasianthum", TUBITAK, 2004.

Publication

21 aem.asm.org

22 Chans, Guillermo M., Antonio Nieto-Camacho,

Teresa Ram rez-Apan, Sim $\mathrm{n}$ Hern ndez-

Ortega, Cecilio Ivarez-Toledano, and 
Elizabeth G mez. "Synthetic, Spectroscopic,

Crystallographic, and Biological Studies of

Seven-Coordinated Diorganotin(iv) Complexes

Derived from Schiff Bases and Pyridinic

Carboxylic Acids", Australian Journal of

Chemistry, 2015.

Publication

Tan Pei Jean. "Bidesmosidic Oleanane

Saponins from Xerospermum noronhianum",

$<1 \%$

Helvetica Chimica Acta, 10!2009

Publication

24 van Wyk, A.W.W.. "Semisynthesis of labdane diterpene metabolites from the nudibranch Pleurobranchaea meckelii", Tetrahedron, 20071203

publication

25 Dinda, Biswanath, Sudhan Debnath, and Yoshihiro Harigaya. "Naturally Occurring Iridoids. A Review, Part 1", CHEMICAL \& PHARMACEUTICAL BULLETIN, 2007.

Fublication

Dinda, Biswanath, Debashis Roy Chowdhury,

and Bikas Chandra Mohanta. "Naturally Occurring Iridoids, Secoiridoids and Their Bioactivity. An Updated Review, Part 3", CHEMICAL \& PHARMACEUTICAL BULLETIN, 2009. 
27. Jun Úzawa. "Pregnane giycosides from the stems of Marsdenia tenacissima", Journal of Asian Natural Products Research, 6/1/2004 Publication

28 Mudianta, I Wayan, Tina Skinner-Adams, Katherine T. Andrews, Rohan A. Davis, Tri A. Hadi, Patricia Y. Hayes, and Mary J. Garson. "Psammaplysin Derivatives from the Balinese Marine Sponge Aplysinella strongylata", Journal of Natural Products, 2012. Publication

Fuad O. Abdullah, Faiq H. S. Hussain, Marco Clericuzio, Alessio Porta, Giovanni Vidari. " A New Iridoid Dimer and Other Constituents from the Traditional Kurdish Plant ", Chemistry \& Biodiversity, 2017

Publication

Xiao-Jing Wang, Gui-Jie Zhang, Peng-Yu Zhuang, Yan Zhang et al. " Lycojaponicumins A-C, Three Alkaloids with an Unprecedented Skeleton from ", Organic Letters, 2012 Publication

31 Riviere, C.. "Chemotaxonomic interest of iridoids isolated from a Malagasy species: Perichlaena richardii", Biochemical Systematics and Ecology, 201108/12 
32. Gangwar, Mayank Goel, R.K. Nath, Gopal.

"Mallotus philippinensis Muell. Arg

(Euphorbiaceae): ethnopharmacology and

phytochemistry review.(Rep", BioMed Research

International, Annual 2014 Issue

Publication

33 scmb.uq.edu.au

Internet Source

34. U. R. Mikkeisen. "Prostaglandin synthesis can

be inhibited locally' by infusion of NSAIDS

through microdialysis catheters in human

skeletal muscle", Journal of Applied

Physiology, 11/21/2007

Publication

35

Shao-Jiang Song, Ling-Zhi Li, Pin-Yi Gao, Ying

Peng, Jing-Yu Yang, Chun-Fu Wu. "Terpenoids and hexenes from the leaves of Crataegus pinnatifida", Food Chemistry, 2011

Puislication

36. Liqin Ding, Feng Zhao, Lixia Chen, Zhihu Jiang, Yue Liu, Zhuomin Li, Feng Qiu, Xinsheng Yao. "New monoterpene glycosides from Paeonia suffruticosa Andrews and their inhibition on NO production in LPS-induced RAW 264.7 cells", Bioorganic \& Medicinal Chemistry Letters, 2012 Publication

Elmi N. Zainuddin, Renate Mentel, Victor Wray, 
Rolf Jansen, Manfred Nimtz, Michael Lalk, Sabine Mundt. " Cyclic Depsipeptides, Ichthyopeptins A and B, from ", Journal of Natural Products, 2007

Publication

38 Gang Ding, Shuchun Liu, Liangdong Guo, Yuguang Zhou, Yongsheng Che " Antifunga! Metabolites from the Plant Endophytic Fungus ", Journal of Natural Products, 2008 Publication

39 De Rosa, S.. "Minor cacospongionolide derivatives from the sponge Fasciospongia cavernose", Tetrahedron, 20070226

41 Jin Li, Tao Wang, Peng Yu, A. Peterson, R. Weber, D. Soerens, D. Grubisha, D. Bennett, J. M. Cook. "General Approach for the Synthesis of Ajmaline/Sarpagine Indole Alkaloids:

Enantiospecific Total Synthesis of (+)-Ajmaline, Alkaloid $G$, and Norsuaveoline via the Asymmetric Pictet-Spengler Reaction", Journal of the American Chemical Society, 1999 Publication

Lee, M.H.. "Bioactive constituents of Spatholobus suberectus in regulating 
tyrosinase-related proteins and mRNA in HEMn cells", Phytochemistry, 200606

Publication

43. Ciavatta, M.L.. "Studies on puupehenonemetabolites of a Dysidea sp.: structure and biological activity", Tetrahedron, 20070205
Publication

44 Naima Boutaghane, Laurenca VoutquenneNazabadioko, Dominique Harakat, Alain Simon, Zahia Kabouche. "Triterpene saponins of Genista ulicina Spach", Phytochemistry, 2013

Publication

45 Shu-hua Qi. "The chemical constituents of Munronia Henryi", Journal of Asian Natural Products Research, 7/1/2003

Publication

46 Hernandez-Guerrero, C.J.. "Sesterterpene metabolites from the sponge Hyatelia intestinalis", Tetrahedron, 20060605 Publication

47 royaigrancanaria.ni

internet Source

48 eprints.soton.ac.uk

internet Source

Min Xu. "Iridoidal glucosides from Gentiana 
rhodantha", Journal of Asian Natural Products Research, 6/2008

50. Yoko Shimokawa, Yusuke Akao, Yusuke Hirasawa, Khalijah Awang et al. " Gneyulins A and $B$, Stilbene Trimers, and Noidesols A and $B$, Dihydroflavonol--Glucosides, from the Bark of ", Journal of Natural Products, 2010 Publication

51 Marcos, I.S.. "Synthetic studies towards picrasane quassinoids", Tetrahedron, 20070305

"Phytochemicals in Human Health Protection, Nutrition, and Plant Defense", Springer Nature, 1999

Liang, Jinru, Yoichiro lto, Xinxin Zhang, Jiao $\mathrm{He}$, and Wenji Sun. "Rapid preparative separation of six bioactive compounds from Gentiana crassicaulis Duthie ex Burk. using microwave-assisted extraction coupled with high-speed counter-current chromatography", Journal of Separation Science, 2013. Publication

Ken Ví.L. Ýong, Aroon Jankam, John N̂.A. Hooper, Apichart Suksamrarn, Mary J. Garson. "Stereochemical evaluation of sesquiterpene 
quinones from two sponges of the genus Dactylospongia and the implication for enantioselective processes in marine terpene biosynthesis", Tetrahedron, 2008

Publication

55 Feng Zhang, Zhi-Jun Wu, Lian-na Sun, Jun Wang, Xia Tao, Wan-Sheng Chen "Iridoid glucosides and a C13=norisoprennid from Lamiophlomis rotata and their effects on NF-KB activation", Bioorganic \& Medicinal Chemistry Letters, 2012

Publication

Li, S.H.. "Novel taxoids from the Chinese yew Taxus yunnanensis", Tetrahedron, 20030101 


\section{Phytochemical Study of Fagraea spp. Uncovers a New Terpene Alkaloid with Anti-Inflammatory Properties}

GRADEMARK REPORT

FINAL GRADE

10
GENERAL COMMENTS

Instructor 